\title{
TTX-Sensitive Dendritic Sodium Channels Underlie Oscillatory Discharge in a Vertebrate Sensory Neuron
}

\author{
Ray W. Turner,, ${ }^{1, a}$ Leonard Maler, ${ }^{1}$ Thomas Deerinck, ${ }^{2}$ S. Rock Levinson, ${ }^{3}$ and Mark H. Ellisman ${ }^{2}$ \\ 'Department of Anatomy and Neurobiology, University of Ottawa, Ottawa, Ontario, Canada K1H 8M5, ${ }^{2}$ Department of \\ Neuroscience, UCSD School of Medicine, La Jolla, California 92093, and ${ }^{3}$ Department of Physiology, University of \\ Colorado Medical School, Denver, Colorado 80262
}

Immunocytochemical and electrophysiological techniques were used to localize TTX-sensitive sodium channels (NaChs) over the soma-dendritic axis of basilar and nonbasilar pyramidal cells of the electrosensory lateral line lobe (ELL) of weakly electric fish (Apteronotus leptorhynchus). Dense NaCh-like immunolabel was detected on the membranes of basilar and nonbasilar pyramidal cell somata. Punctate regions of immunolabel $(\sim 15 \mu \mathrm{m})$ were separated by nonlabeled expanses of membrane over the entire extent of basal dendrites. Similar punctate immunolabel was observed over the apical dendrites, and frequently on membranes of afferent parallel fiber boutons in the distal apical dendritic region.

Intracellular recordings from pyramidal cell somata or proximal apical dendrites (75-200 $\mu \mathrm{m}$ ) were obtained using an in vitro ELL slice preparation. TTX-sensitive potentials were identified by focal pressure ejection of TTX. Somatic recordings demonstrated both $\mathrm{TTX}$-sensitive fast spike discharge and a slow prepotential; similar but lower amplitude potentials were recorded in apical dendrites. Dendritic spikes were composed of at least two active components triggered by a fast prepotential (FPP) generated by the somatic spike. TTX-sensitive spikes propagated in a retrograde fashion over at least the proximal $200 \mu \mathrm{m}$ of the apical dendrites, as determined by the conduction of an antidromic population spike and focal TTX ejections. Somatic spikes were followed by a depolarizing afterpotential (DAP) that was similar in duration and refractory period to that of proximal dendritic spikes. During repetitive spike discharge, the DAP could increase in amplitude and attain somatic spike threshold, generating a high-frequency spike doublet and a subsequent hyperpolarization that terminated spike discharge. Repetition of this process gave rise to an oscillatory burst discharge (2-6 spikes/burst) with a frequency of $40-80 \mathrm{~Hz}$. Both the DAP and oscillatory discharge were selectively blocked by TTX ejections restricted to the proximal apical dendritic region.

\footnotetext{
Received Sept. 7, 1993; revised Mar. 22, 1994; accepted Apr. 21, 1994.

This research was supported by a Canada MRC grant to L.M., an NIH grant to S.R.L. from NINDS (NS 15879), and NIH grants to M.H.E. from NINDS (NS 14718 and NS 26739) and from NCRR (P41 RR04050). R.W.T. was supported by a Canada MRC Centennial Fellowship. We thank W. Staines for the use of photomicrographic facilities, J. Plant for helpful discussions, and L. Borg and W. Ellis for technical assistance.

Correspondence should be addressed to Dr. L. Maler at the above address.

a Present address: Department of Medical Physiology, University of Calgary, 3330 Hospital Drive N.W., Calgary, Alberta, Canada T2N 4N 1 .

Copyright (C) 1994 Society for Neuroscience $0270-6474 / 94 / 146453-19 \$ 05.00 / 0$
}

The present study demonstrates an immunolocalization of NaChs over somatic and dendritic membranes of a vertebrate sensory neuron that correlates with the distribution of TTX-sensitive potentials. The interaction of somatic and dendritic action potentials is further shown to underlie an oscillatory discharge believed to be important in electrosensory processing.

[Key words: sodium channel, action potential, dendritic spike, oscillation, depolarizing afterpotential, prepotentials, electric fish, electrolocation, fast prepotential (FPP)]

Voltage-dependent $\mathrm{NaChs}$ have long been recognized as an important determinant of neuronal excitability, with the diversity of $\mathrm{NaChs}$ becoming increasingly apparent with biochemical and molecular analyses of $\mathrm{NaCh}$ structure and function (Sarao et al., 1991; Catterall, 1992; Mandel, 1992; Schaller et al., 1992). The role for $\mathrm{NaChs}$ in determining cellular activity is further shown by a differential distribution at the regional and subcellular level (Mandel, 1992) and in the wide range of neuronal activities incorporating $\mathrm{NaCh}$ activation (Stafstrom et al., 1982, 1985; Llinas, 1988; Alonso and Llinas, 1989; Schwindt et al., 1989; Stys et al., 1993; Turner et al., 1993).

At the subcellular level, NaChs have been localized cytochemically in both intact and cultured neurons to axon nodes of Ranvier (Ellisman and Levinson, 1982; Black et al., 1989; Devor et al., 1989; England et al., 1990), the initial segment (Catterall, 1981; Wollner and Catterall, 1986; Angelides et al., 1988), and somatic membrane (Angelides et al., 1988; Westenbroek et al., 1989; Caffrey et al., 1992). Although cytochemical studies have demonstrated $\mathrm{NaChs}$ on neurites of cultured neurons (Catterall, 1981; Boudier et al., 1985; Angelides et al., 1988), most evidence for NaChs localized to dendritic membrane has been obtained through electrophysiological analysis (Benardo et al., 1982; Huguenard et al., 1989; Masukawa et al., 1991; Turner et al., 1991a, 1993; Jaffe et al., 1992; Kim and Connors, 1993; Stuart and Sakmann, 1994). Dendritic recordings from hippocampal and neocortical pyramidal cells provide evidence that these channels can promote the retrograde conduction of a spike from soma to dendrite, or boost the weight of synaptic transmission by initiating a spike at the dendritic level (Wong et al., 1979; Turner et al., 1989, 1991a, 1993; Amitai et al., 1993; Kim and Connors, 1993; Stuart and Sakmann, 1994).

In the present study we combined immunocytochemical and electrophysiological techniques to identify the subcellular distribution and function of TTX-sensitive $\mathrm{NaCh}$ in somatic and dendritic regions of a vertebrate sensory neuron. We have cho- 
sen for several reasons to work with pyramidal cells of the electrosensory lateral line lobe (ELL) of the weakly electric fish Apteronotus leptorhynchus (brown ghost knife fish). First, antibodies prepared to the TTX-binding protein ( $\mathrm{NaCh} \alpha$-subunit) of Electrophorus electrocytes (Ellisman and Levinson, 1982) recognize brain $\mathrm{NaChs}$ of this related gymnotiform weakly electric fish (Devor et al., 1989). Secondly, gymnotiform fish are a favorable neuroethological system in which to study sensory processing related to both electrolocation and electrocommunication (Bastian, 1986a, 1990; Bullock and Heiligenberg, 1986; Heiligenberg et al., 1991; Metzner and Heiligenberg, 1991). ELL pyramidal cells, in particular, have been extensively analyzed in vivo with regard to the encoding of spatial and temporal characteristics of electrosensory input during the behavior of electrolocation (Saunders and Bastian, 1984; Bastian, 1986b, 1990; Shumway, 1989; Bastian and Courtright, 1991). Finally, the large size, laminar distribution, and conspicuous dendritic structure of pyramidal cells make them an ideal cell type to investigate the subcellular function(s) of $\mathrm{NaChs}$ in a vertebrate neuron.

Our work demonstrates that TTX-sensitive NaChs are distributed over somatic and dendritic membranes of ELL pyramidal cells. Intrasomatic and -dendritic recordings further reveal a soma-dendritic interaction in $\mathrm{Na}^{+}$spike generation that underlies an oscillatory discharge relevant to electrosensory processing.

Some of this work has been presented in abstract form (Ellisman et al., 1988).

\section{Materials and Methods}

Tissue fixation. The ELL of Apteronotus leptorhynchus was prepared for immunohistochemical reaction and analysis by light or clectron microscopy (LM, EM). Fish of 15-25 gm weight were perfused with phosphate-buffered saline $(0.9 \% \mathrm{NaCl}, 0.1 \mathrm{M}, \mathrm{pH} 7.2)$ (PBS) containing $4 \%$ paraformaldehyde (PARA) for LM or $0.01 \mathrm{M}$ periodate, $0.075 \mathrm{M}$ lysine, $2 \%$ paraformaldehyde (PL/PARA) for EM (McLean and Nakane, 1974; Maler et al., 1981). The brain was blocked at the level of optic tectum and postfixed for $1 \mathrm{hr}$ in PARA (LM) or PL/PARA (EM). Transverse slices of the medulla were cut by Vibratome (LM, $250 \mu \mathrm{m} ; \mathrm{EM}, 80 \mu \mathrm{m}$ ) under microscopic observation in cold $\left(4^{\circ} \mathrm{C}\right)$ PBS and blocked to a trapezoid configuration containing the ELL.

Tissue processing for light microscopic immunohistochemistry. Tissue destined for LM was prepared for sectioning by cryomicrotomy. Tissue blocks were cryoprotected by sequential placement in chilled PARA (1\%) containing $0.5 \mathrm{M}, 1.0 \mathrm{M}$, and $2.3 \mathrm{~m}$ sucrose for periods of $30 \mathrm{~min}$, $30 \mathrm{~min}$, and $2 \mathrm{hr}$, respectively. Tissue blocks were then mounted onto slot pins in PBS containing $2.3 \mathrm{~m}$ sucrose, fast frozen in liquid propane or freon, and stored in liquid nitrogen. Semithin sections of $0.5-1.5 \mu \mathrm{m}$ thickness were cut at $-64^{\circ} \mathrm{C}$ (Reichart Ultracut E), mounted on gelcoated slides, and placed in a moist chamber.

Fluorescent double-labeling was used to reveal $\mathrm{NaChs}$ and pyramidal cell structure. $\mathrm{NaCh}$ immunolabel was obtained using a polyclonal anti$\mathrm{NaCh}$ antibody (1:100) developed against the TTX-binding protein ( $\mathrm{NaCh} \alpha$-subunit) of electric organ (Ellisman and Levinson, 1982). A monoclonal anti-tubulin antibody $(1: 20$; Boehringer) counterstained tubulin-containing pyramidal cell structures. Sections were treated at room temperature according to standard immunocytochemical procedures using horse anti-mouse IgG-biotin ( $1: 50$; Vector) and donkey anti-rabbit IgG-fluorescein (1:20; Amersham), and streptavidin-Texas red (1:200; Amersham). The wash solution through the application of sccondary antibodies was PBS, $0.05 \mathrm{M}$ glycine, $0.5 \%$ gelatin, $0.5 \%$ normal horse serum (Vector), and PBS thereafter. Slides were coverslipped with antifade medium (PBS, $90 \%$ glycerol, $0.1 \% p$-phenylenediamine; $\mathrm{pH} 10$ ), sealed with nail polish, and stored at $-20^{\circ} \mathrm{C}$.

Tissue processing for preembedding immunohistochemistry. Tissue blocks for $\mathrm{EM}$ were reacted at $4^{\circ} \mathrm{C}$ using the anti-NaCh antibody (1: 100), Goat anti-rabbit IgG (1:100; Amersham), and a rabbit peroxidaseantiperoxidase complex (1:200; Amersham). The working solution up to the postsecondary washes was a Tris-buffered saline $(50 \mathrm{~mm}, \mathrm{pH} 7.3)$ (TBS) containing $0.5 \%$ glycine, $1 \%$ bovine serum albumin, $1 \%$ normal goat serum. The peroxidase label was revealed by preincubation of tissue sections in diaminobenzidine $(0.5 \mathrm{mg} / \mathrm{ml})$ and subsequent addition of $0.02 \% \mathrm{H}_{2} \mathrm{O}_{2}$. Sections were osmicated in TBS, $1 \%$ osmium for $30 \mathrm{~min}$ and washed in distilled water. Sections were then dehydrated through an ethanol (EtOH) and EtOH/acetone/Epon-Araldite series for immersion in epoxy resin before flat embedding and polymerization at $60^{\circ} \mathrm{C}$ overnight. Tissue sections were mounted on Epon blocks and $70 \mathrm{~nm}$ sections cut and placed on 200 mesh grids.

Preparation of in vitro slices. ELL slices were prepared for in vitro recording using a technique modified from Mathieson and Maler (1988). Fish of 10-15 gm weight were immobilized by intramuscular injection of $2 \%$ Flaxedil-100 (0.1-0.2 ml, Rhone-Poulenc) and positioned on a custom-made stereotaxic apparatus. The gills were superfused with oxygenated tank water $\left(95 \% \mathrm{O}_{2}, 5 \% \mathrm{CO}_{2}\right)$ through a burette in the fish's mouth, and anesthesia provided by $0.2 \% 3$-aminobenzoic acid ethyl ester (MS-222; Sigma) or 0.05\% 2-phenoxy-ethanol (Sigma) in the superfusate. The tissue overlying the skull was dissected away under microscopic observation, and the cranium lifted away with forceps after cutting along the lateral cranial sutures with iridectomy scissors. The brain was superfused with an oxygenated $\left(95 \% \mathrm{O}_{2}, 5 \% \mathrm{CO}_{2}\right)$ artificial cerebrospinal fluid (ACSF) consisting of (in mM) $124 \mathrm{NaCl}, 3 \mathrm{KCl}, 0.75$ $\mathrm{KH}_{2} \mathrm{PO}_{4}, 1.6 \mathrm{CaCl}_{2}, 1.2 \mathrm{MgSO}_{4}, 24 \mathrm{NaHCO}_{3}$, and 10 D-glucose, $\mathrm{pH}$ 7.4. Continual oxygenation of the medulla to this point was confirmed by examining the rate of venous return in vessels exiting and coursing over the ELL surface. A micro-scalpel was used to cut the anterior lateral line nerve at the ventrolateral surface of the medulla, sever the spinal cord, and block the brain at a $\sim 45^{\circ}$ angle at the level of optic tectum. The fish was then immersed in cold $\left(4^{\circ} \mathrm{C}\right)$ preoxygenated ACSF and the brain lifted out with a spatula.

The rostral surface of the brain was attached to a precooled aluminum block with cyanoacrylite glue and surrounded with gelatin ( $20 \%$ in distilled water) ejected from a previously warmed syringe $\left(\sim 28^{\circ} \mathrm{C}\right)$ to provide support during slice preparation; $550 \mu \mathrm{m}$ slices were cut by vibratome under microscopic observation in a chamber filled with cold oxygenated $\operatorname{ACSF}\left(4^{\circ} \mathrm{C}\right)$. Excess gelatin was trimmed from a slice using forceps and iridectomy scissors, and the slice floated onto a spatula rostral side up for transfer to an in vitro recording chamber. Slices were maintained as an "interface preparation" at room temperature by perfusion of oxygenated ACSF (1-2 $\mathrm{ml} / \mathrm{min}$ ) and superfusion of humidified $95 \% \mathrm{O}_{2}, 5 \% \mathrm{CO}_{2}$ gas. Dissection was completed in $\sim 15 \mathrm{~min}$ and the tissue allowed $1.5 \mathrm{hr}$ for recovery and equilibration before recordings were carried out.

Stimulating and recording procedures. Square wave stimulating pulses were delivered through isolation units $(0.1 \mathrm{msec}, 1-50 \mathrm{~V}$; Digitimer SIU) to bipolar stimulating electrodes (twisted $62 \mu \mathrm{m}$ nichrome wire) placed on pyramidal cell axons within the plexiform layer. Extracellular recording electrodes were broken back under microscopic observation to a tip diameter of $1-2 \mu \mathrm{m}$ and backfilled with HEPES (10 mM; $N-2-$ hydroxyethanepiperizine- $N$ '-2-ethane sulfonic acid)-buffered Ringer's solution consisting of (in $\mathrm{mM}$ ) $148 \mathrm{NaCl}, 3.75 \mathrm{KCl}, 1.6 \mathrm{CaCl}_{2}, 1.2 \mathrm{MgCl}_{2}$, $10 \mathrm{D}$-glucose; $\mathrm{pH} 7.4,310 \mathrm{mmol} / \mathrm{kg}$ (10-30 M $\Omega$ resistance). Glass intracellular recording electrodes were backfilled with $2 \mathrm{~m}$ potassium acetate (50-100 $\mathrm{M} \Omega$ resistance). All electrical activity was referenced to an $\mathrm{Ag} / \mathrm{AgCl}$ bath ground (extracellular, $\mathrm{AC}$ coupled; intracellular, DC to $10 \mathrm{kHz}$ bandpass), digitized, and led to a microcomputer for storage and off-line analysis (Axon Instruments, pCLAMP).

Intracellular recordings were obtained primarily in the centromedial segment of transverse ELL slices, and in some cases, from the centrolateral segment. Recordings in longitudinally oriented slices could not be classified according to segmental map, but were likely from the centrolateral or lateral segments. Cells included for data analysis exhibited large-amplitude spikes $(>70 \mathrm{mV})$ and a characteristic discharge pattern in response to current injection. Laminar profiles of extracellular field potentials were collected by the sequential placement of a recording electrode over the pyramidal cell soma-dendritic axis. The distance between recording locations was calculated by reference to the average value of each stratum previously measured in cresyl violet-stained tissue sections. Potentials at each site were recorded 50-75 $\mu \mathrm{m}$ deep to the surface, and three responses were collected for signal averaging. Average values are expressed as mean \pm SEM with samples chosen randomly for cases in which total $n>15$. Statistical significance was determined using the Student's $t$ test.

Focal pressure application of pharmacological agents. Pharmacological agents were focally applied to somatic or dendritic regions by adding drugs to the electrolyte of extracellular recording electrodes (see above; Turner et al., 1989). Air pressure pulses applied to the side port of the 

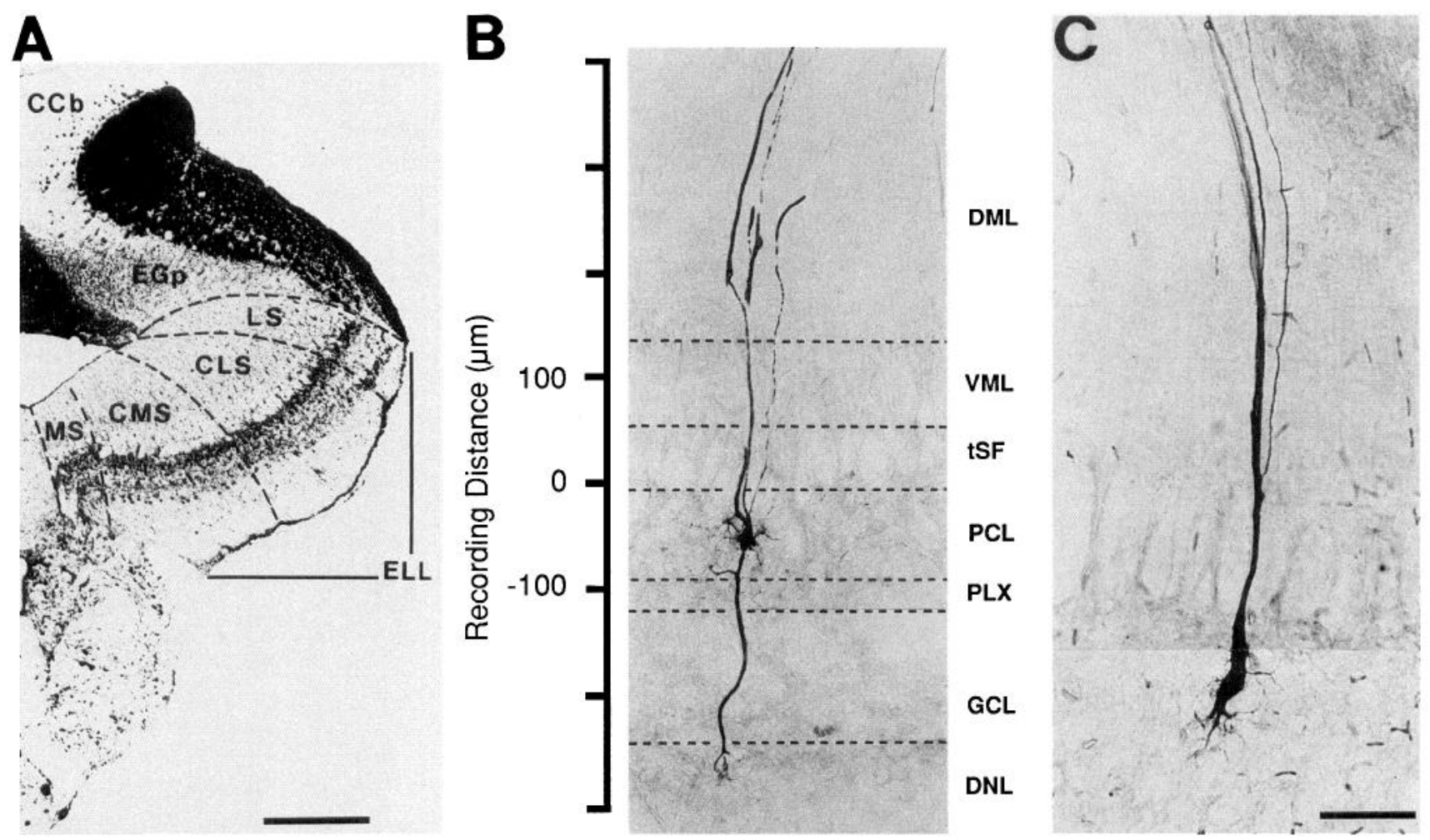

Figure 1. A, Cresyl violet-stained transverse section through the rhombencephalon of Apteronotus leptorhynchus illustrating the position of the electrosensory lateral line lobe $(E L L)$ and its constituent topographic maps. The ELL is interposed between the brainstem and the overlying cerebellar lobes, the eminentia granularis pars posterior $(E G p)$, and the corpus cerebelli $(C C b)$. Dashed lines in the ELL indicate the boundaries between four topographic maps of the body surface, the medial $(M S)$, centromedial $(C M S)$, centrolateral $(C L S)$, and lateral $(L S)$ segments. Cell body layers course in a mediolateral direction across each segmental map. $B$, Expanded view of a CMS basilar pyramidal cell in relation to the various lamina of the ELL (dashed lines). Primary afferent input to the basal dendrite terminates in the deep neuropil layer $(D N L)$ at the boundary of the granule cell body layer ( $G C L$; cell bodies not apparent). Pyramidal cell somata are located within the pyramidal cell body layer ( $P C L)$, bounded by the plexiform layer $(P L X)$ ventrally and the tSF dorsally. The prominent apical dendrites of pyramidal cells course through the tSF and a molecular layer divided into ventral $(V M L)$ or dorsal $(D M L)$ divisions according to the termination of descending feedback inputs. $C$, Slightly enlarged view of a nonbasilar pyramidal cell, illustrating the lack of a basal dendrite and the prominent apical dendrite extending through the tSF, VML, and DML. Cells were labeled by intrasomatic biocytin injection and streptavidin-HRP. Scale bars: $A, 500 \mu \mathrm{m} ; C, 50 \mu \mathrm{m}$.

electrode holder (70-200 msec, 5-15 psi) ejected drugs in the immediate location of the extracellular recording site. A direct visual estimate of the initial radius of drug application was obtained in dendritic regions under transillumination. Ejection time and pressure for somatic ejections was first established by testing the electrode in molecular regions of cerebellum distant from the recording site. Confirmation of drug diffusion away from the ejection site was obtained by monitoring potentials at adjacent sites that were previously shown to be sensitive to the ejected drug. A rapid, local effect was thus achieved by adjusting drug concentrations to $\sim 10$ times greater than that normally effective when bath applied, as discussed in Turner et al. $(1989,1991 \mathrm{a}) . \mathrm{MgCl}$ and $\mathrm{KCl}$ replaced $\mathrm{MgSO}_{4}$ and $\mathrm{KH}_{2} \mathrm{PO}_{4}$ in the slice medium when ejecting $\mathrm{Mn}^{2+}$ or $\mathrm{Cd}^{2+}$ in order to prevent precipitation. Ejection of the carrier medium alone had no effect. The use of this technique permitted us to block somatic or apical dendritic NaChs selectively by ejecting TTX onto either side of the tractus stratum fibrosum fiber bundle (tSF; $\sim 75$ $\mu \mathrm{m}$ ); the tSF appears to act as an effective barrier against drug diffusion between the pyramidal cell body and molecular layers. Evidence for this comes from delays of up to $2 \mathrm{~min}$ in detecting the effects of an ejected drug on potentials recorded from the other side of the tSF. In contrast, potentials recorded within $100 \mu \mathrm{m}$ of an ejection site on the same side of the $\mathrm{tSF}$ can be affected within $10 \mathrm{sec}$.

Intracellular biocytin injections and tissue processing. Cells were identified anatomically using a technique modified from Horikawa and Armstrong (1988). Biocytin (Sigma) was made up as a $2 \%$ solution in $2 \mathrm{~m}$ potassium acetate titrated via acetic acid to $\mathrm{pH} 7.2$, restricting biocytin injections to positive currents greater than $\sim 1.2 \mathrm{nA}(10-30 \mathrm{~min}$ pulsed or DC). Background peroxidase activity was eliminated from $80 \mu \mathrm{m}$ Vibratome sections by immersion in $0.3 \% \mathrm{H}_{2} \mathrm{O}_{2} / \mathrm{PBS}$ for $10 \mathrm{~min}$. HRP was revealed using DAB $(0.2 \mathrm{mg} / \mathrm{ml})$ in $0.1 \mathrm{M}$ sodium acetate buffer (pH 6.0) reacted with $0.2 \%$ glucose and $0.075 \%$ glucose-oxidase (Sigma).

\section{Results}

Structure of the ELL and pyramidal neurons

The ELL has a distinct laminar structure consisting of a deep fiber layer composed of primary afferent fibers, a deep neuropil layer containing primary afferent terminals, a layer of granular interneurons, a plexiform layer of pyramidal cell efferent fibers, and a pyramidal cell body layer (Fig. 1A). Pyramidal cell somata are confined to the pyramidal cell layer while their apical dendrites project dorsally through the tSF and a molecular layer subdivided into ventral (VML) and dorsal (DML) divisions (Fig. $1 B$ ). The tSF is composed of thin myelinated afferent axons that forms a prominent visual landmark, clearly separating the pyramidal and molecular layers (Maler, 1979; Maler et al., 1982). The VML contains terminating tSF afferent fibers, and the DML, parallel fibers emanating from granule cells in the overlying cerebellum. The exact boundary between the VML and DML cannot be seen directly in unstained tissue, but is $\sim 200 \mu \mathrm{m}$ from the $\mathrm{tSF} /$ pyramidal cell layer boundary. The ELL is subdivided into four segmental topographic maps: medial, centromedial, centrolateral, and lateral (Fig. 1A; Carr and Maler, 1986; Maler et al., 1991). The present study focused only on the last three of these segments, as they receive input from tuberous electroreceptors and function as a spatiotemporal filter of electrosensory input (Carr and Maler, 1986; Maler, 1989; Shumway, 1989).

Pyramidal cells give rise to thick proximal apical dendrites 
$(6-8 \mu \mathrm{m})$ that penetrate the $\mathrm{tSF}$ in bundles and branch $\sim 100$ $\mu \mathrm{m}$ from the cell body near the junction of the tSF and VML (Fig. $1 B, C$ ). These branches ramify through the VML and DML over a distance $\sim 550 \mu \mathrm{m}$ to form a planar arborization $\sim 100$ $\mu \mathrm{m}$ wide parallel to the longitudinal axis of the ELL (Saunders and Bastian, 1984). Basilar pyramidal cells (approximately half the population) have a thick basal dendrite $(\sim 10 \mu \mathrm{m})$ that penetrates the plexiform layer and runs vertically for $200-400 \mu \mathrm{m}$ to ramify in the deep neuropil layer (Fig. $1 B$ ). A second pyramidal cell type, the nonbasilar pyramidal cell, lacks a basal dendrite (Fig. 1C) and can thus be distinguished histologically on the basis of a rounded soma and the presence of numerous small somatic dendrites. A thin axon $(<2.0 \mu \mathrm{m})$ typically emanates from the soma of pyramidal cells and projects rostromedially in the plexiform layer (Maler, 1979). Previous anatomical studies have shown that the above characteristics are sufficient to differentiate pyramidal cells from other cell types in this region (i.e., VML and polymorphic cells; Maler, 1979; Maler et al., 1981).

\section{Immunocytochemistry of $\mathrm{NaCh}$ distribution}

Electron microscopic studies have shown that both the apical and basal dendrites of pyramidal cells are characterized by numerous evenly spaced microtubules (Maler et al., 1981). Antibodies directed against $\beta$-tubulin were therefore effective as an immunolabel counterstain for dendrites and various myelinated fibers. The tubulin antibody also provided sufficient label of cell somata to allow identification of basilar versus nonbasilar pyramidal cells (Fig. $2 A, C$ ).

$\mathrm{NaChs}$ were labeled using a polyclonal antibody raised against the TTX-binding protein isolated from the electric organ of Electrophorus electricus (Ellisman and Levinson, 1982). A similar selectivity of the antibody for Apteronotus brain NaChs was shown by Devor et al. (1989), and confirmed here by elimination of immunostaining by preabsorption with purified Electrophorus $\mathrm{NaChs}$ (Fig. $2 D$ ). NaCh immunolabel was exclusively found in association with the surface membrane of pyramidal cells, with no staining of internal organelles. The somata of both basilar and nonbasilar pyramidal cells were densely but unevenly immunostained by the $\mathrm{NaCh}$ antibody (Fig. $2 B$ ), with small immunoreactive patches separated by unlabeled regions. $\mathrm{NaCh}$ immunolabel was also observed surrounding the somata of smaller cells within the pyramidal cell layer (Fig. $2 B$ ); cells identified as polymorphic interneurons on the basis of their size, shape, and dendritic orientation (Maler, 1979). The immunolabel observed on pyramidal cell somata continued onto the proximal portions of both apical and basal dendrites. Sections of the small diameter axon hillock and initial segment of these cells (Maler, 1979) were not obtained at either the light or EM level.

The entire extent of the thick descending trunk of pyramidal cell basal dendrites was covered with small puncta of $\mathrm{NaCh}$ immunolabel (Fig. 3B). In some cases, tight clusters of immunolabel were separated by longer regions of unlabeled dendrite. These could be seen at the ultrastructural level as small patches of immunoreactivity associated with the basal dendritic membrane (Fig. 3C). The label did not appear to be associated with areas of synaptic contact (Fig. 3C) or the terminal bush of the basal dendrite, the region in receipt of primary afferent input. However, the thin nature of these latter dendritic branches may have prevented us from detecting them.

In the proximal apical dendrites, $\mathrm{NaCh}$ immunolabel was readily detected at both the light and ultrastructural level as distinct puncta separated by regions of unlabeled membrane (Figs, $2 B, 4 A, B$ ). The patchy distribution of immunolabel in this case was not due to the presence of intervening boutons since there are few synapses on pyramidal cell dendrites in this region. Rather, nonimmunoreactive dendritic membrane was in contact with glia or the myelinated fibers of the tSF (Fig. 4B). In addition, these results cannot be attributed to penetration problems with immunocytochemical reagents, as glutamate immunoreactivity at the EM level can be seen as a diffusely distributed label throughout the internal region of apical dendrites (Wang and Maler, unpublished observations).

At the light microscopic level, $\mathrm{NaCh}$ immunolabel in the DML was observed as small puncta that followed the distal arborization of pyramidal cell apical dendrites (Fig. $5 B$ ). At the ultrastructural level, immunolabel was found in clear association with the surface of parallel fiber boutons that contact the spines of pyramidal cell apical dendrites (Fig. 5C; Maler, 1979; Maler et al., 1981). Immunopositive particles could also be seen adjacent to the shafts of distal apical dendrites (Fig. $5 C$, arrowhead), although no evidence was obtained for $\mathrm{NaCh}$ immunolabel on any portion of the dendritic spine or subsynaptic apparatus.

\section{Electrophysiology of pyramidul cells in vitro}

The electrical activity of membrane regions demonstrating $\mathrm{NaCh}$ immunoreactivity was examined by intracellular recordings from pyramidal cell somata or apical dendrites using an in vitro ELL slice preparation (Mathieson and Maler, 1988). No recordings were made from pyramidal cell basal dendrites. Pyramidal cells were identified either histologically or by electrophysiological characteristics. Somatic impalements were obtained within the boundaries of the pyramidal cell body layer $(n=86)$; recognized in vitro as a gray strata flanked by the white myelinated fibers of the tSF and plexiform layers (Fig. 1B). Apical dendritic recordings were obtained $>75 \mu \mathrm{m}$ from the pyramidal cell body layer near the boundary of the tSF and VML $(n=21)$. Each of these impalements displayed a similar pattern of repetitive spike discharge and could be antidromically activated by stimulation of the plexiform layer in longitudinally oriented slices. Antidromic activation establishes that these recordings are from pyramidal cell apical dendrites, since neurons within the tSF and molecular layer project locally (Maler, 1979). Impalements of neuronal structures within the tSF that exhibited similar characteristics were taken to represent proximal apical dendritic recordings $(n=5)$. Intracellular injection of biocytin into recordings at either the somatic $(n=28)$ or apical dendritic level $(n=6)$ revealed a basilar or nonbasilar pyramidal cell structure (Fig. 1B,C). A series of such injections also allowed us to distinguish between pyramidal cells and other cell types (i.e., polymorphic cells, VML neurons, and tSF axons) on the basis of electrophysiological characteristics (Turner and Maler, unpublished observations; Maler, 1979). As resting membrane characteristics did not differ substantially between basilar and nonbasilar pyramidal cells, measurements were combined unless otherwise noted.

Pyramidal cell somata and apical dendrites exhibited similar resting potentials and input resistances (Table 1), with linear voltage/current plots over a membranc potential range of -90 $\mathrm{mV}$ to $-65 \mathrm{mV}$ in both locations (Fig. $6 A, B$ ). A voltage- and time-dependent slow prepotential could be observed in some cells above $\sim-60 \mathrm{mV}$ (primarily somatic recordings) as a slow increase in the slope of a depolarization near spike threshold 

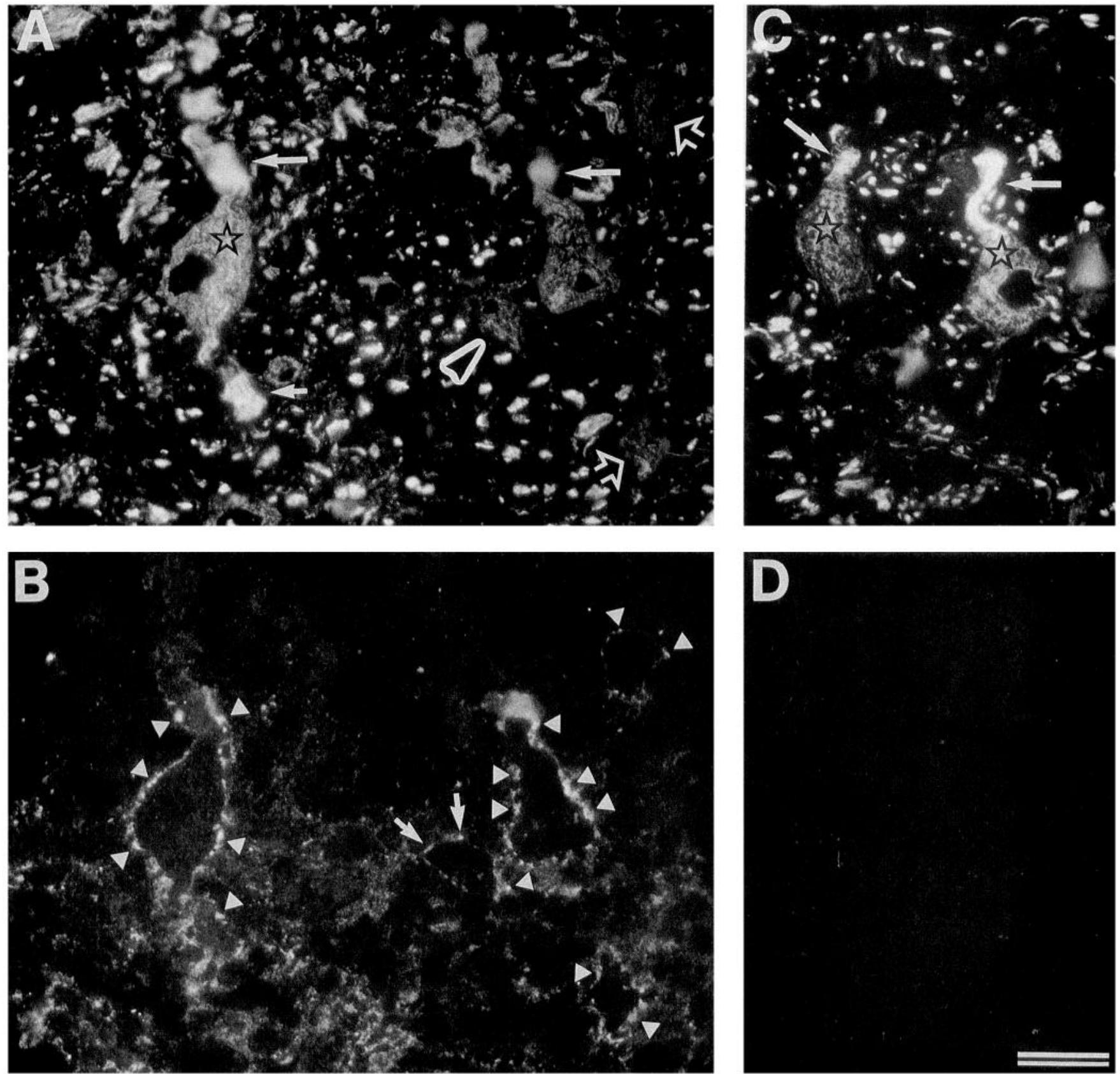

Figure 2. Pyramidal cell somata and proximal dendrites exhibit $\mathrm{NaCh}$ immunolabel. $A-D$ are photomicrographs of $1.5 \mu \mathrm{m}$ sections of the pyramidal cell body layer double labeled for tubulin $(A, C)$ and $\mathrm{NaCh}$ immunoreactivity $(B, D)$. $A$, Tubulin immunolabel reveals a basilar and nonbasilar pyramidal cell (stars), together with proximal portions of apical dendrites (arrows) and basal dendrite (small arrow). The cell bodies of two possible pyramidal cells (open arrows) and a polymorphic cell (arrowhead) can also be detected. Numerous cross-sectioned processes in the immediate region are apparent in tubulin-stained tissue. $B, \mathrm{NaCh}$ immunoreactivity is distributed over the somatic membrane of basilar and nonbasilar pyramidal cells, and continues onto the proximal apical and basal dendritic trunks in a more punctate fashion (arrowheads). NaCh immunolabel can also be observed on the polymorphic cell somata (arrows). $C$, Tubulin-immunolabeled section of the pyramidal cell body layer indicating two pyramidal cell somata (stars) with proximal apical dendritic trunks (arrows). D, Preabsorption of $\mathrm{NaCh}$ antibody with purified electroplax NaChs eliminates immunolabel. Scale bar, $20 \mu \mathrm{m}$.

(Figs. 6A, 7; Mathieson and Maler, 1988). The voltage threshold for action potential discharge evoked by depolarizing current also appeared to be similar in soma and apical dendrite, with values above resting membrane potential in the soma of 11.1 $\pm 0.89 \mathrm{mV}(n=20)$ and $10.9 \pm 0.89 \mathrm{mV}(n=14)$ in dendritic recordings (see Discussion).

At the somatic level, spikes evoked by depolarizing current were of large amplitude and short half-width (Table 1) and discharged near threshold as a train of spikes with a characteristically slow onset (lag) and subsequent increase in the frequency of discharge (Fig. 6C; Mathieson and Maler, 1988). Current-evoked spikes were followed by a fast afterhyperpolarization (fAHP) and a slow afterhyperpolarization (sAHP). In some cells, a depolarizing afterpotential (DAP) was interposed between the fAHP and sAHP (described in Fig. 12). In dendritic impalements, current-evoked depolarizations near spike threshold 

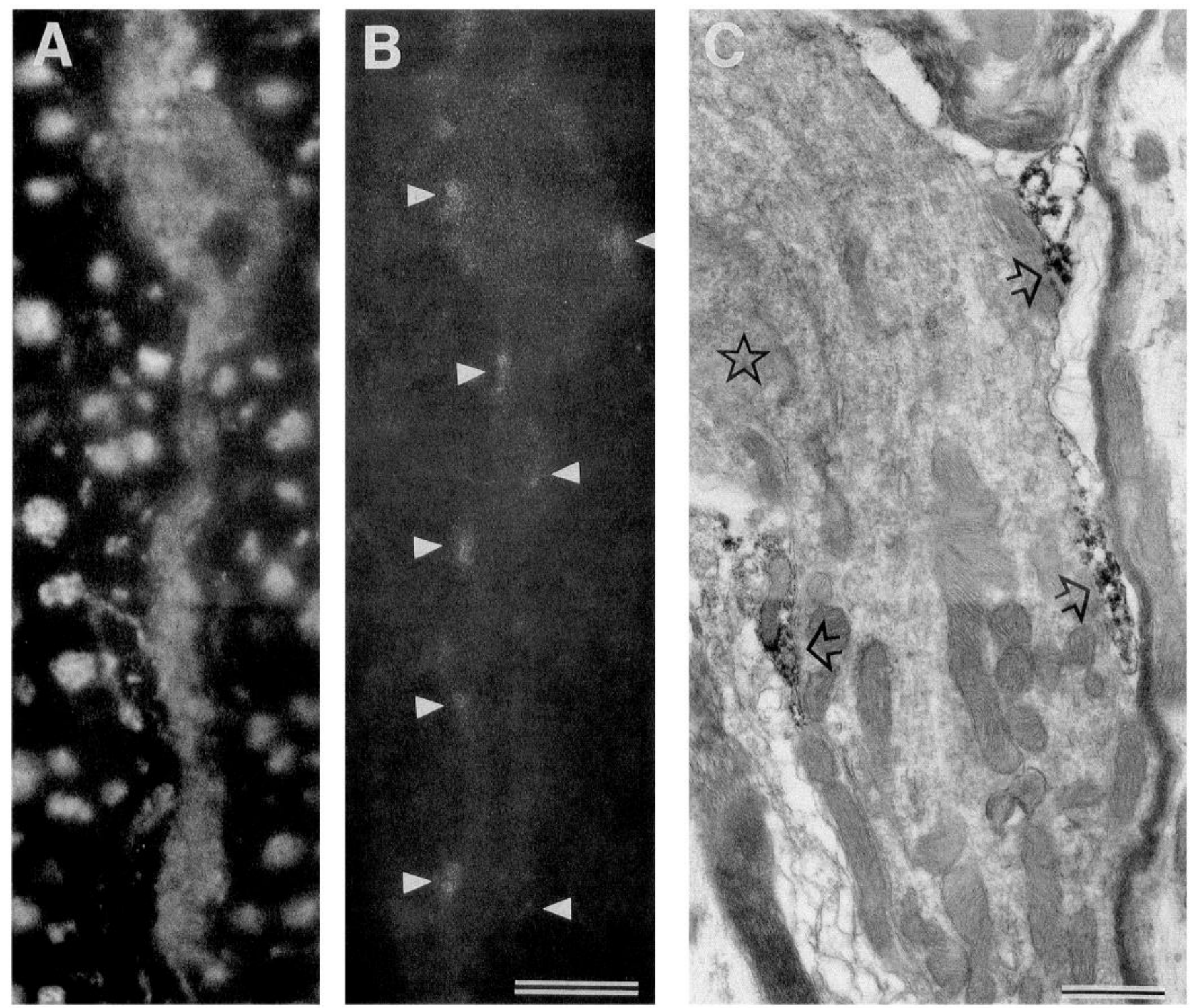

Figure 3. Pyramidal cell basal dendrites exhibit punctate regions of $\mathrm{NaCh}$ immunolabel. $A$ and $B$, Low-power photomicrographs of a basilar pyramidal cell double labeled for tubulin $(A)$ and $\mathrm{NaCh}(B)$ immunoreactivity in a $1.5 \mu \mathrm{m}$ tissue section. $A$, Tubulin immunolabel identifies the pyramidal cell body and thick basal dendrite projecting ventrally towards the DNL, surrounded by numerous tubulin-stained processes cut in cross section. $B, \mathrm{NaCh}$ immunoreactivity is distributed in a punctate manner on basal dendritic membrane (arrowheads), with immunoreactive sites separated by long regions of nonreactive membrane. Immunoreactive sites are also apparent on somatic membrane. $C$, Electron micrograph of $\mathrm{NaCh}$-immunoreactive sites on a pyramidal cell basal dendrite. Note the association of $\mathrm{NaCh}$ immunolabel with the surface of basal dendritic membrane (open arrows), but not an impinging synaptic bouton in the upper left of the photograph (star). Scale bars: $A$ and $B, 10 \mu \mathrm{m} ; C, 2 \mu \mathrm{m}$.

evoked a similar pattern of repetitive spike discharge with an initial lag and subsequent increase in discharge frequency (Fig. $6 D$ ). Dendritic spikes, however, were of significantly lower amplitude and longer half-width than somatic spikes (Table 1) and lacked an fAHP, although a low-amplitude sAHP was present. Antidromic spikes in the soma were evoked with an amplitude of $88.0 \pm 2.89 \mathrm{mV}$ and half-width of $0.39 \pm 0.02 \mathrm{msec}(n=$ $20)$ and in the apical dendrites, $66.6 \pm 3.79 \mathrm{mV}$ and $1.3 \pm 0.18$ $\operatorname{msec}(n=10 ;$ Fig. $6 E, F)$. Although these values appear different from those in Table 1, antidromic spikes evoked upon a subthreshold current-evoked depolarization virtually superimposed upon those evoked by current injection alone (data not shown). Again, antidromic somatic spikes were followed by an fAHP and sAHP but only an SAHP was apparent at the dendritic level. The presence of a DAP interposed between the FAHP and
SAHP was more readily observed on antidromic spikes at the somatic level (Fig. 6E).

\section{$T T X$ sensitivity of somatic and dendritic potentials}

The contribution of $\mathrm{NaChs}$ to somatic or dendritic activity was directly tested by focal ejection of TTX in the immediate vicinity of intrasomatic or -dendritic recordings (see Materials and Methods). For intrasomatic recordings, TTX ejections in either the pyramidal or plexiform layer rapidly reduced spike frequency prior to inducing a complete failure of spike discharge (Fig. $7 A-C ; n=12$ ). During this process, a slow prepotential of up to $10 \mathrm{mV}(4.8 \pm 0.84 \mathrm{mV} ; n=9)$ became increasingly apparent as a slowly rising depolarization (Fig. $7 C$ ), accounting for an apparent increase in voltage threshold as spike frequency dropped. The slow prepotential was also blocked by TTX, but 

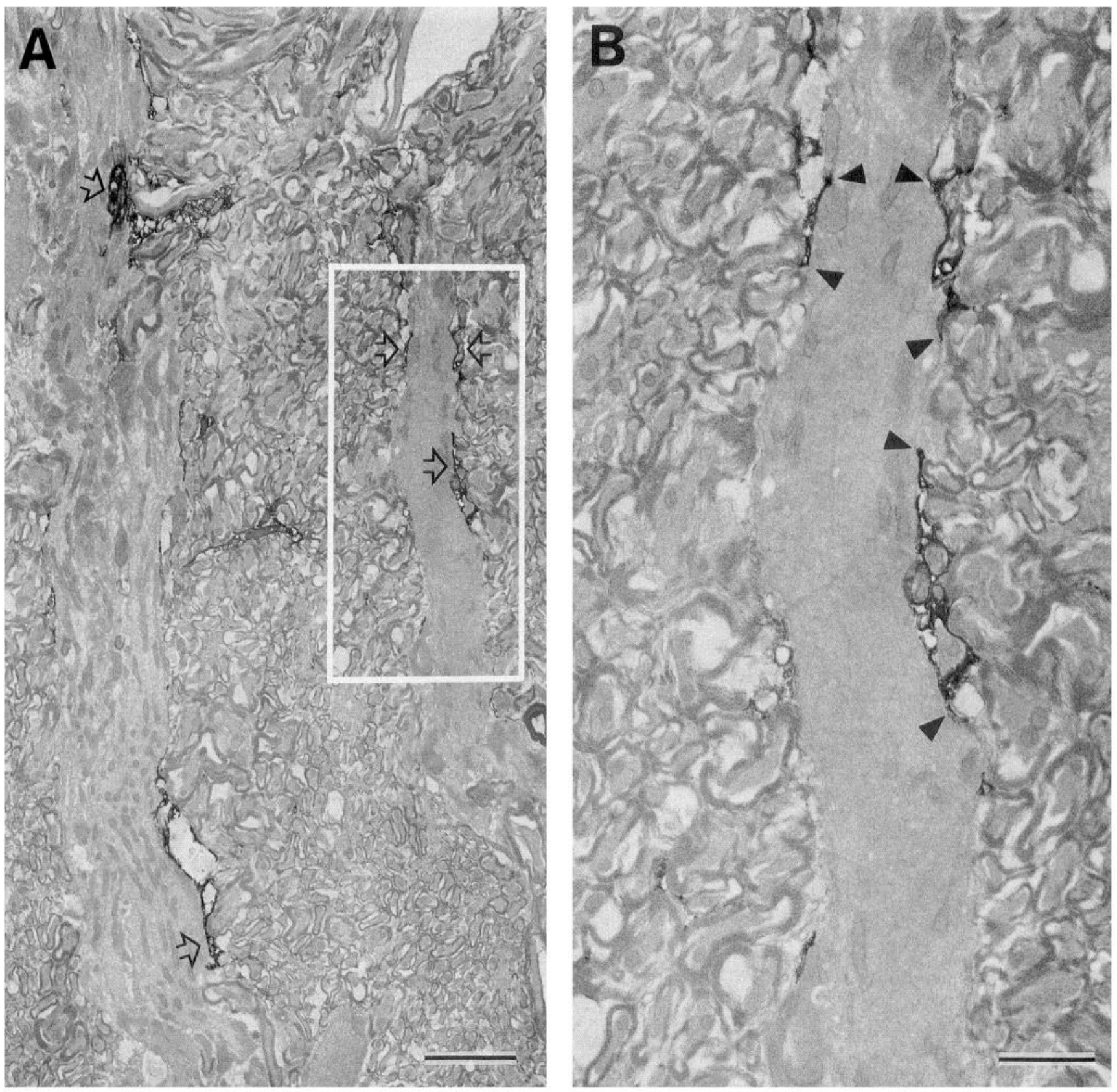

Figure 4. The proximal portion of pyramidal cell apical dendrites $(<200 \mu \mathrm{m})$ exhibit punctate regions of NaCh immunolabel. A, Electron micrograph of two proximal apical dendrites of pyramidal cells coursing through the cross-sectioned myelinated axons that comprise the thick tSF fiber bundle. Note the punctate distribution of $\mathrm{NaCh}$ immunolabel in association with apical dendritic membrane (open arrows), with occasional staining of putative nodes of Ranvier of the surrounding tSF axons. $B$, Higher-power micrograph of the section of dendrite boxed in $A$ illustrating punctate $\mathrm{NaCh}$ immunoreactivity (regions denoted by arrowheads) adjacent to membranes of the proximal apical dendrite. Some buildup of PAP reaction product is observed in the extracellular space adjacent to immunoreactive sites. Scale bars: $A, 5 \mu \mathrm{m} ; B, 2 \mu \mathrm{m}$.

always subsequent to the failure of evoked spikes. The latter results were obtained with the shortest separation in time for TTX ejections in the plexiform layer. Neither potential could be evoked by higher levels of current injection immediately after blockade by TTX (data not shown). TTX ejections in either the pyramidal or plexiform layer produced up to a $6 \mathrm{mV}$ hyperpolarizing shift in resting potential $(2.1 \pm 0.55 \mathrm{mV} ; n=12)$ but no measurable change in input resistance $(n=7)$.

In contrast to somatic recordings, focal TTX ejections in the immediate region of a dendritic impalement rarely produced a direct failure of dendritic spike discharge. Instead, spikes rapidly decreased in amplitude and then fractionated in form to reveal a repeating cluster of smaller active responses (Fig. $8 B, C ; n=$ $7 / 8$ ). These were composed of a comparatively large initial spike and two smaller active potentials of $<2$ msec duration ("partial spikes" appearing as small inflections on the falling phase of the initial spike). As TTX took effect, the partial spikes were evoked at progressively longer latencies, increasing the overall duration of each dendritic spike. TTX blocked the late partial spikes within seconds (Fig. $8 \mathrm{C}$ ) and reduced the amplitude of the initial 

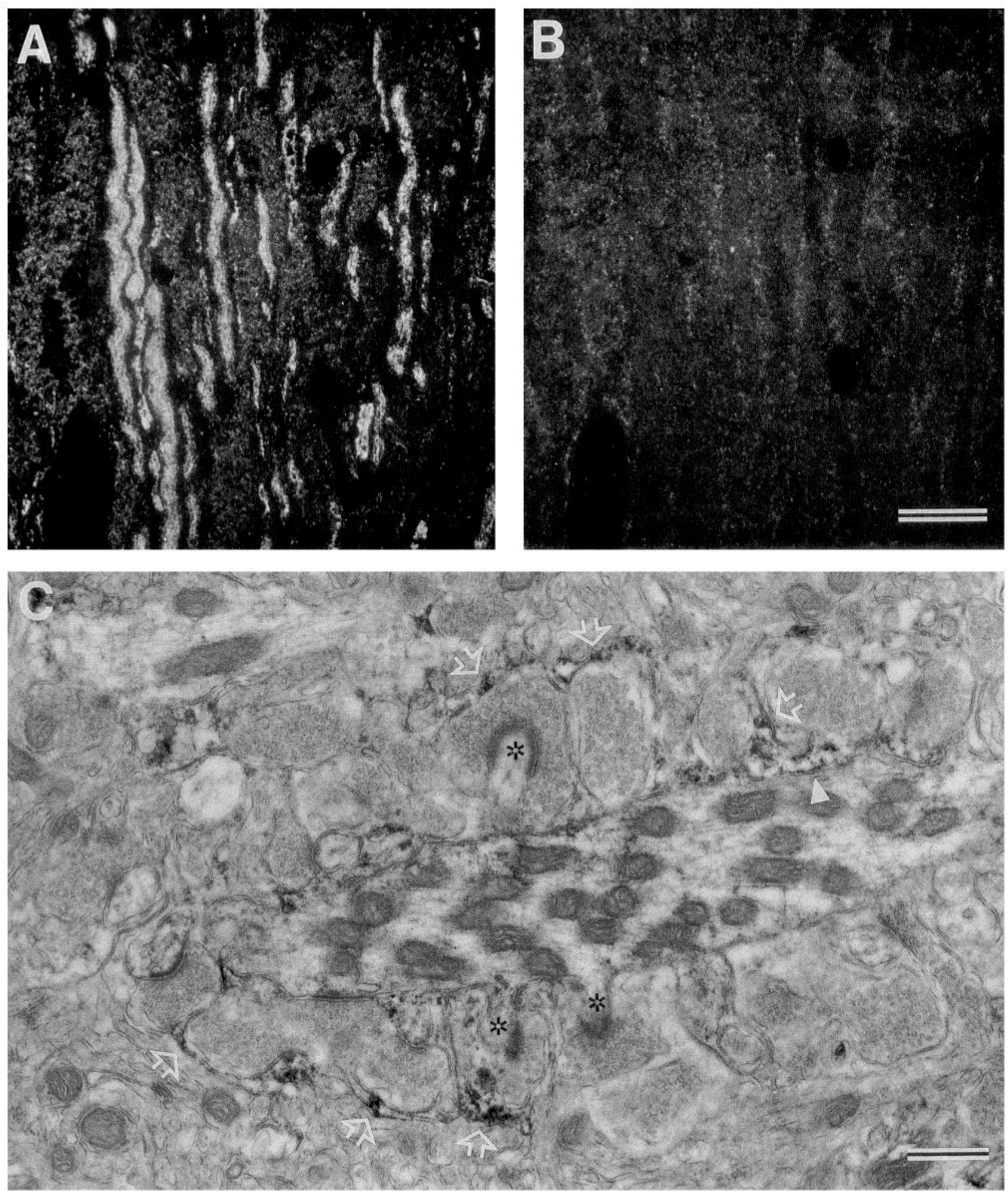

Figure 5. NaCh immunolabel of distal pyramidal cell apical dendrites and synaptic terminals. $A$ and $B$, Low-power photomicrographs of a 1.5 $\mu \mathrm{m}$ section of the ELL dorsal molecular layer containing pyramidal cell distal apical dendrites double stained for tubulin $(A)$ and $\mathrm{NaCh}(B)$ immunoreactivity. $A$, Tubulin immunolabel indicates several apical dendrites projecting dorsally through the DML. $B, \mathrm{NaCh}$ immunolabel appears as small puncta that outline the structure of distal apical dendrites. $C$, Electron micrograph of a longitudinally sectioned pyramidal cell apical dendrite in the DML. Immunolabel (open arrows) is often detected juxtaposed between glial membranes and parallel fiber boutons that synapse on pyramidal cell dendritic spines (asterisks). In contrast, $\mathrm{NaCh}$ immunolabel is only occasionally detected immediately adjacent to apical dendritic membrane (arrowhead). Immunolabel was not detected in association with the neck, head, or postsynaptic density of several apical dendritic spines. Scale bars: $A$ and $B, 20 \mu \mathrm{m} ; C, 2 \mu \mathrm{m}$. 


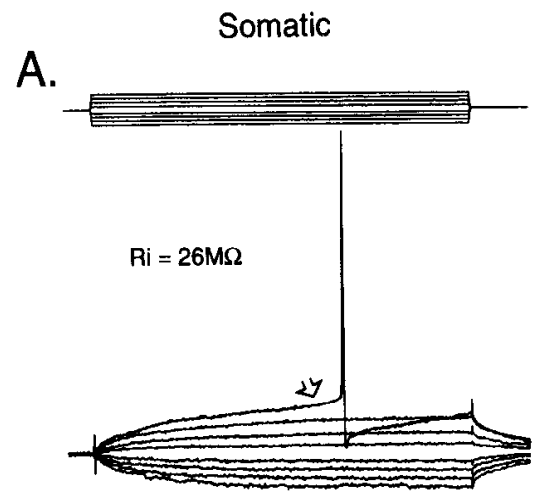

C.

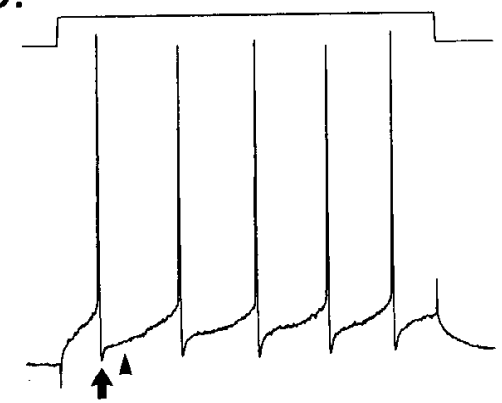

E.

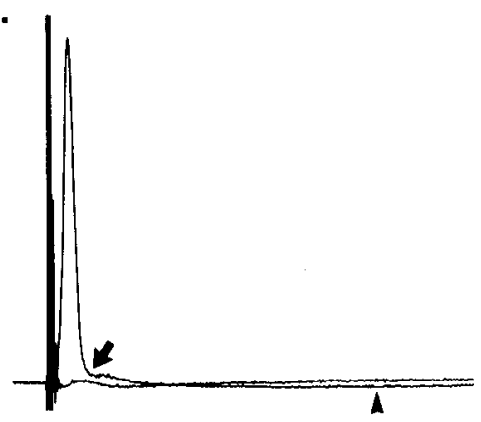

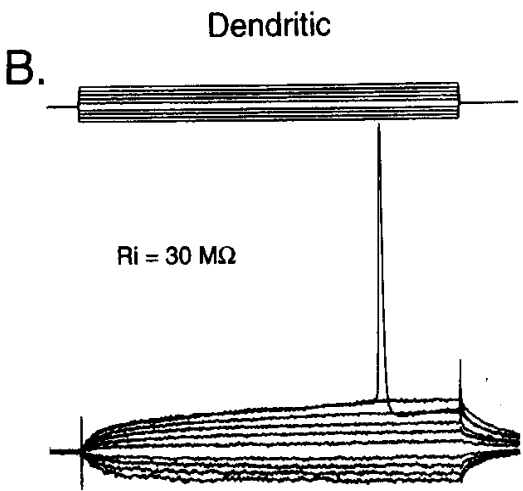

D.

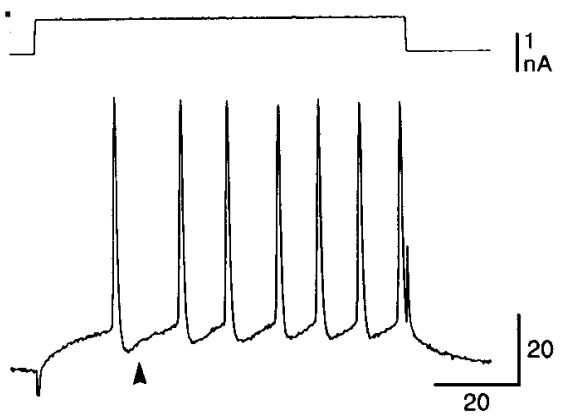

F.

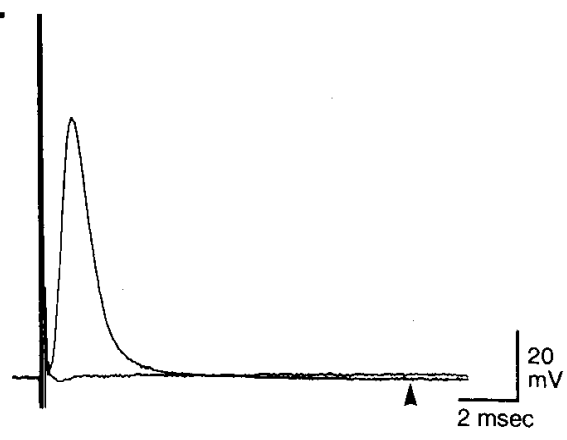

Figure 6. Electrophysiological characteristics of pyramidal cell somatic and apical dendritic recordings. $A$ and $B$, Representative membrane potential response of somatic $(A)$ and dendritic $(B)$ recordings to a set of square wave current pulse injections $(90 \mathrm{msec})$. A slow depolarizing prepotential is apparent in the soma as a gradual increase in the slope of the depolarization underlying spike discharge ( $A$, open arrow). Input resistance $(R i)$ was similar in either location. $C$ and $D$, Injection of depolarizing current in somatic $(C)$ or apical $(D)$ dendritic impalements evoked similar repetitive spike trains, characterized by an initial lag and subsequent increase in spike frequency. Somatic spikes were of larger amplitude and shorter duration than dendritic spikes, and were followed by an fAHP (arrow) and SAHP (arrowhead). Dendritic spikes were followed only by an sAHP $(D$, arrowhead). $E$ and $F$, Stimulation of pyramidal cell axons in the plexiform layer evoked an all-or-none antidromic spike directly from baseline at both the somatic $(E)$ and dendritic $(F)$ level (recordings at just sub- and suprathreshold intensity are shown superimposed). Both an fAHP (arrow) and an SAHP (arrowhead) followed the antidromic somatic spike, while a smaller sAHP was present in the apical dendrite (arrowhead). A DAP observed in somatic recordings is most apparent in $E$ interposed between the antidromic spike fAHP and sAHP. spike to a potential of $16-29 \mathrm{mV}$ (Fig. $8 D ; n=7$ ). Since the initial spike appeared to be essential for discharge of the subsequent TTX-sensitive components and could be evoked by antidromic stimulation (Fig. $8 D$ ), we refer to it as a "fast prepotential" (FPP) (Spencer and Kandel, 1961; Carras et al., 1992; Turner et al., 1993).

Dendritic FPPs were relatively TTX resistant in that repeated ejection of the toxin was required over several minutes before blockade was achieved $(n=2)$. Therefore, in order to determine the origin of the FPP, TTX ejections were stopped in six cases shortly after FPPs were uncovered. The TTX-containing elec- trode was then repositioned in the cell body layer directly beneath and at the same depth as the intradendritic impalement (Fig. $8 E$ ). TTX ejection in the cell body layer rapidly decreased the frequency and then blocked both current-evoked and antidromic FPPs recorded in the apical dendrite (Fig. $8 F, G$ ). TTX ejection in the cell body layer also uncovered a small slow prepotential in four of eight dendritic recordings that was blocked subsequent to the failure of FPPs (Fig. $8 G ; 2.3 \pm 0.26 \mathrm{mV} ; n$ $=4$ ). No further activity could be evoked at this time by increasing depolarizing current. As found for somatic recordings, TTX ejection was accompanied by a hyperpolarizing shift of up

Table 1. Comparison between membrane properties and current-evoked action potentials in pyramidal cell somata and apical dendrites

\begin{tabular}{lll} 
& Somata & Apical dendrites \\
\hline Resting membrane potential $(\mathrm{mV})$ & $68.3 \pm 0.97, n=20$ & $68.9 \pm 1.14, n=20$ \\
Input resistance $(\mathrm{M} \Omega)$ & $26.7 \pm 1.89, n=20$ & $28.7 \pm 2.52, n=20$ \\
Action potential height $(\mathrm{mV})$ & $81.4 \pm 1.98, n=20$ & $67.5 \pm 1.97, n=20^{* * *}$ \\
Action potential half-width (msec) & $0.35 \pm 0.03, n=20$ & $0.84 \pm 0.06, n=20^{* * *}$
\end{tabular}

Action potential height is measured from threshold to peak depolarization; half-width is the spike duration at half amplitude. Data are mean + SEM.

**** $p<0.001$, two-tailed Student's $t$ test. 
A.

Figure 7. Focal ejection of TTX in the pyramidal cell body layer blocks the somatic spike and slow prepotential. $A$, Schematic diagram illustrating an intrasomatic recording in the pyramidal cell layer ( $P C L$; not drawn to size), and the placement of a pressure electrode for focal ejection of $16 \mu \mathrm{M}$ TTX in the PCL (shaded region). The horizontal lines separating the PCL and VML denote the thick tSF fiber bundle, while the truncated basal dendrite signifies that results refer to both basilar and nonbasilar pyramidal cells. $B$, Control intrasomatic response to depolarizing current injection. $C$, TTX ejection rapidly reduced somatic spike frequency prior to inducing a complete failure of spike discharge $(<10 \mathrm{sec})$. A slow prepotential (open arrows) that became apparent as spike frequency dropped was subsequently blocked by TTX (three traces superimposed in C, bottom). TTX also induced a membrane hyperpolarization of $6 \mathrm{mV}$ (resting potential shown by $C$, bottom, solid arrow). $D$, Recovery of spike and slow prepotential $25 \mathrm{~min}$ after TTX ejections. The current pulse shown in $B$ applies to all recordings.

to $5 \mathrm{mV}$ in resting potential $(3.0 \pm 0.58 \mathrm{mV} ; n=7)$ but no measurable change in input resistance $(n=4)$.

Pyramidal cells are not known to form gap junction connections or exhibit dye coupling to neighboring pyramidal cells (Maler et al., 1981; Mathieson and Maler, 1988). Therefore, dendritically recorded FPPs are not likely to represent spikes electrotonically conducted across gap junctions between adjacent pyramidal cells (MacVicar and Dudek, 1982). We thus interpret the blockade of dendritic FPPs by TTX ejection at the cell body layer as evidence that these potentials represent depolarizations generated by somatic action potential discharge (Turner et al., 1993).

\section{Antidromic spike discharge over the soma-dendritic axis}

We were unfortunately prevented from repeating the above experiments for dendritic sites in the DML, as these structures could not recover a stable resting potential following the initial impalement. We therefore tested for the presence of $\mathrm{Na}^{+}$-dependent potentials in distal dendritic regions by determining the extent of invasion by an evoked antidromic spike. For this purpose most analysis was carried out on identified extracellular spike responses.

Comparison of intra- and extracellular potentials revealed that the rising edge of both somatic and dendritic antidromic spikes aligned with a short-latency extracellular field potential negativity (Fig. $9 A, B ; n=6$ ). These were evoked with up to 5 $\mathrm{mV}$ amplitude and $1.2 \mathrm{msec}$ duration in the pyramidal cell body layer, and $1.5 \mathrm{mV}$ and $2.0 \mathrm{msec}$ duration in the VML (Fig. 9A$C ; n=6$ ). The field potential negativity was graded in amplitude in both locations and increased directly with plexiform stimulus intensity. Each of the above characteristics were taken to identify these potentials as antidromic "population spikes" reflecting synchronous spike discharge in the pyramidal cell population.

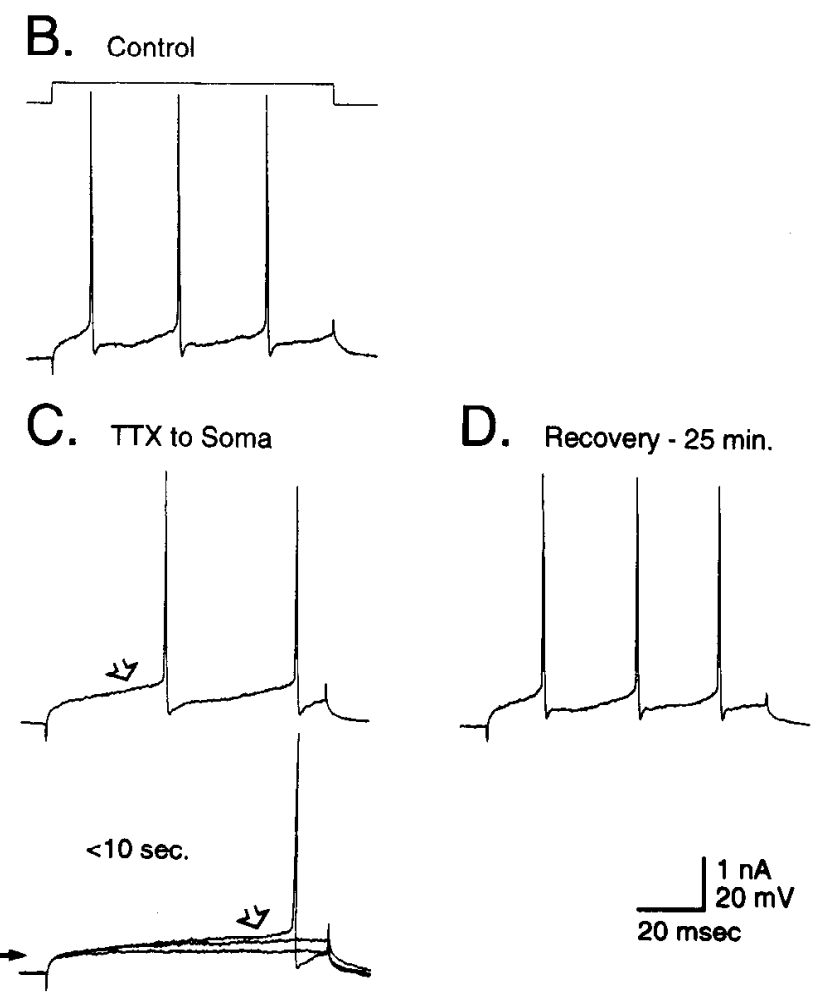

We therefore used the population spike to measure the extent of antidromic spike invasion of pyramidal cell apical dendrites.

Laminar profiles of plexiform-evoked responses revealed a prominent antidromic population spike only over a restricted region of the pyramidal cell axis, largest in amplitude and shortest in latency in the pyramidal and plexiform layers (Fig. 9C,D). A noticeable decrease in amplitude and an increase in the latency of the population spike was found at the junction of the pyramidal cell body layer and the tSF. An even greater change in these parameters was observed at the tSF/VML border and through the remaining DML (Fig. 9D). The duration of the population spike changed in a similar manner, increasing from $1.1 \pm 0.05 \mathrm{msec}$ in the plexiform layer to $2.3 \pm 0.04 \mathrm{msec}$ in the mid-DML $(n=6)$.

In dendritic regions, a short-duration positivity preceded the population spike, giving rise to a biphasic positive-negative potential (Fig. $9 C$; tSF - DML). The early positivity had a peak latency similar to that of the cell body population spike, and increased in duration and amplitude with dendritic recording distance. As this pattern of activity is essentially identical to that observed for dendritic spike invasion in other laminar structures (Jefferys, 1979; Richardson et al., 1987), we interpret it as an outward current associated with the invasion of a spike from more proximal regions. A second positive-going potential of longer duration (2.5-4.5 msec) could follow antidromic population spikes. This potential was most prominent in the plexiform and pyramidal layers ( $1.3 \pm 0.06 \mathrm{mV} ; n=6$; see below).

The largest antidromic population spike was thus found in the plexiform and pyramidal cell body layers, regions containing the axons and cell bodies of pyramidal cells, respectively. The population spike invaded at least the proximal portion of pyramidal cell apical dendrites, but rapidly slowed in conduction velocity above the $\mathrm{tSF}$; decreasing from $1.23 \mathrm{~m} / \mathrm{sec}$ in the plexi- 
A.

$\pi \times 1$ - VML

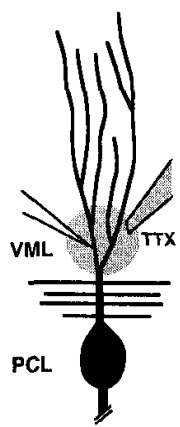

B.

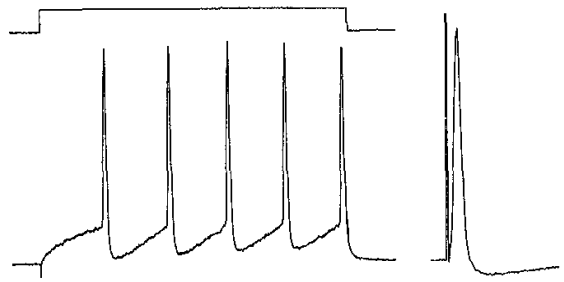

C. Post TTX $<30$ sec.

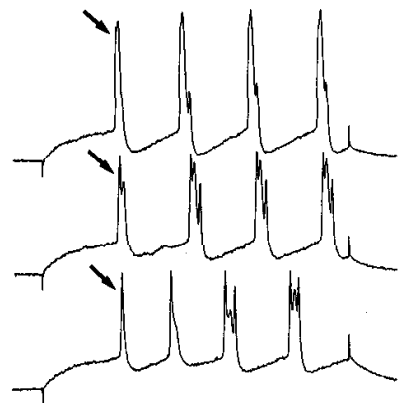

D. Post TTX 2 min.

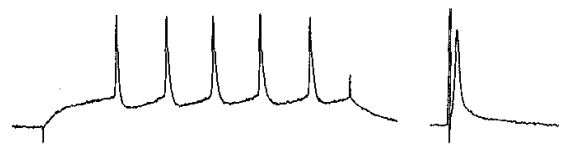

E. TTX2 - PCL

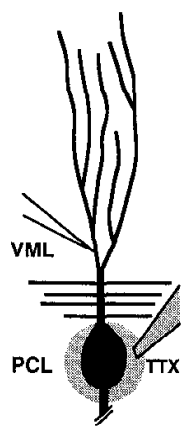

F
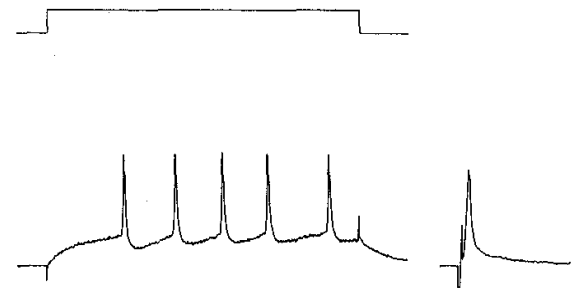

G. Post TTX $<10 \mathrm{sec}$
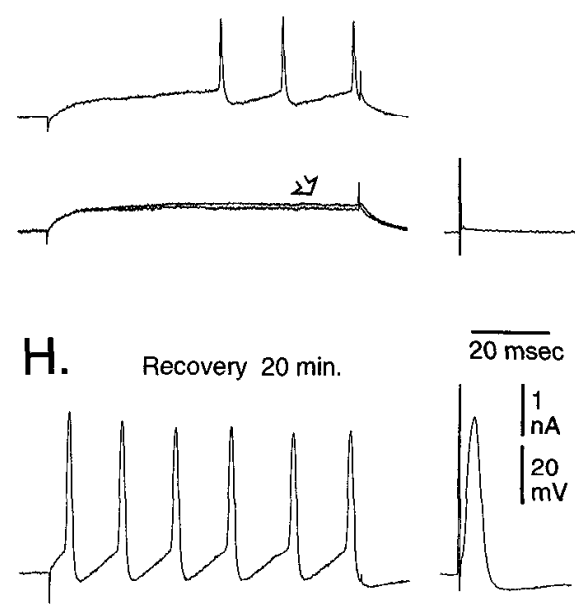

Figure 8. Focal cjcction of TTX blocks the dendritic spike and reveals a FPP of somatic origin. $A$ and $E$, Schematic diagrams illustrating pyramidal cells, the intradendritic recording site in the VML, and the sites for sequential ejection of $16 \mu \mathrm{M}$ TTX in the VML $(A-D)$ and then the PCL $(E-G$, shaded regions). The horizontal lines denote the thick tSF fiber bundle, while the truncated basal dendrite signifies that results refer to both basilar and nonbasilar pyramidal cells. $B$, Control intradendritic spike discharge evoked by current injection is shown on the left and the plexiform-evoked (antidromic) dendritic spike is shown on the right. $C$ and $D$, Focal TTX ejections in the immediate region of the recording site fractionated the dendritic spike, revealing an initial FPP (arrows) and two subsequent active events (partial spikes) that can be detected as small inflections on the falling edge of the FPP. The FPP decreased in size within $30 \mathrm{sec}$, but the later partial spikes were blocked. $D$, The comparatively TTX-resistant FPP could be evoked by either current injection or antidromic stimulation $2 \mathrm{~min}$ after TTX ejections in the VML. $E$ and $F$, The TTX electrode was relocated to the cell body layer directly below the dendritic recording site, and a second set of controls recorded. $G$, TTX ejections in the PCL rapidly reduced FPP frequency (upper records) and then blocked both current- and plexiform-evoked FPPs within a 10 sec period (lower records). A small slow prepotential that became apparent after FPP blockade was subsequently blocked by TTX (open arrow). $H$, Recovery of spike discharge 20 min after TTX cjections. Current pulses shown in $B$ and $F$ apply to all recordings in their respective columns. The stimulus artifacts were truncated in $D, G$, and $H$. form/pyramidal layers to $0.37 \mathrm{~m} / \mathrm{sec}$ above the $\mathrm{tSF}$ and through the DML (estimated from the time to peak of the antidromic population spike negativity).

\section{Localization of TTX-sensitive antidromic potentials}

The above transformations in the population spike suggested that the nature of antidromic spike invasion of apical dendrites changed above the level of the tSF. We therefore used focal TTX ejections to assess the contribution of NaChs to the conduction of the antidromic population spike over different regions of the cell axis.

Focal ejections of TTX through an extracellular recording electrode in the plexiform or pyramidal cell body layers rapidly reduced the amplitude or blocked the antidromic population spike in these regions (Fig. 10A;n=5). As diffusion of TTX between the pyramidal and VML layers is impcded by the thick tSF fiber bundle (see Materials and Methods), a simultaneous decrease of the VMI population spike (Fig. 10A) was consistent with a dependence of dendritic spike discharge upon that at the cell body. A TTX sensitivity of the VML dendritic population spike is shown in Figure 10B. TTX ejections through a VML recording electrode reduced the VML population spike by $45-$ $97 \%$ prior to any reduction of the cell body population spike negativity (Fig. $10 B ; n=11$ ). In contrast to the above results, TTX ejections in the DML had no effect on the antidromic potential (Fig. 10C, DML 1; $n=12$ ). Reduction of the DML population response could only be obtained if repeated ejections promoted sufficient diffusion of TTX to reduce the population spike in the VML (Fig. 10C, VML 2). Similar results were obtained for all DML recording sites over $\sim 200 \mu \mathrm{m}$ from the pyramidal cell body layer.

The above experiments demonstrate that TTX-sensitive conductances contribute to the conduction of an antidromic spike over the cell body and proximal region of the apical dendritic axis $(<200 \mu \mathrm{m})$. Although the continued conduction of an active response through some portion of the DML is suggested by the 

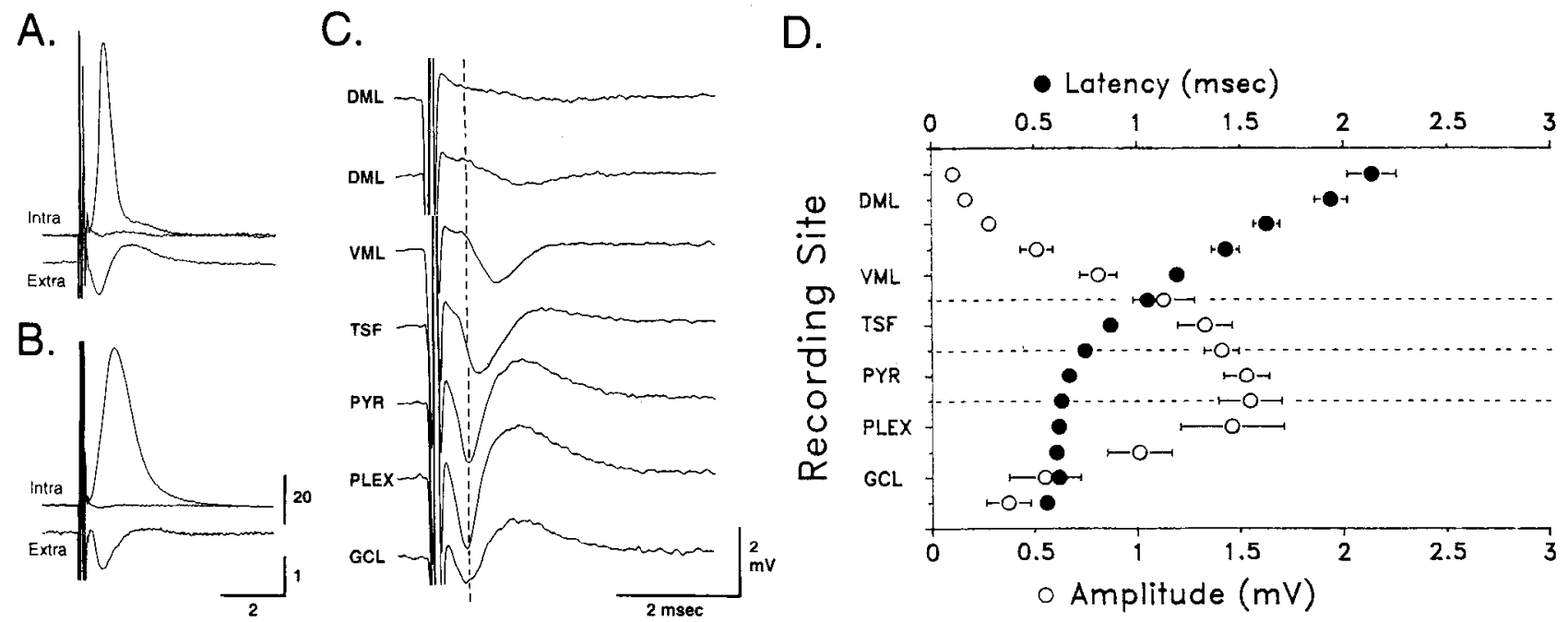

Figure 9. Evoked antidromic spikes retrogradely invade the proximal apical dendrites of pyramidal cells. $A$ and $B$, Comparison of intrasomatic $(A)$ and intradendritic $(B)$ spikes (Intra) to their respective extracellular field potentials (Extra) recorded immediately following withdrawal from the impalements. In either location, the rising phase and peak of the intracellular spike aligns temporally with a negative-going population spike. $C$, A laminar profile of antidromic field potentials over the pyramidal cell axis recorded at the locations indicated. A dashed line is drawn through the peak of the population spike negativity in the pyramidal cell layer to facilitate latency comparisons. $D$, Plots of the average peak amplitude (open circles) and peak latency (solid circles) of the antidromic field potential negativity over the pyramidal cell axis $(n=6)$. Plexiform stimulus intensity was adjusted in each case to evoke a $\sim 1.5 \mathrm{mV}$ population spike negativity in the pyramidal cell layer. The boundaries between major strata are shown by dashed lines. Note the progressive change in peak amplitude and latency of the negative-going field potential over the apical dendritic axis. A more rapid transition in both parameters was detected near the branch point of proximal apical dendrites at approximately the tSF/VML border. Field potential responses are averaged records of three consecutive sweeps. Average values in $D$ without error bars are those in which the bars fall within the boundary of the illustrated point.

presence of a small antidromic field negativity (Figs. 9, 10C), this response appears to be generated by TTX-insensitive conductances.

\section{The effects of dendritic spike discharge upon somatic activity}

A curious result of the above study was that blockade of thc VML population spike by TTX was accompanied by a $48 \pm$ $8.7 \%$ reduction of the late field potential positivity in the cell body layer (Fig. 10B; $n=11$ ). This was unexpected, as a local field positivity reflects a net outward flow of current to the extracellular space; usually the result of active ionic or synaptic conductances in the immediate (somatic) region. We therefore applied several pharmacological blocking agents to identify the conductance(s) underlying the field positivity following the somatic antidromic population spike. Neither $\mathrm{Cl}^{-}$nor $\mathrm{Ca}^{2+}$ conductances appeared to be involved, as focal pressure ejections of picrotoxin ( $25 \mu \mathrm{M} ; n=3), \mathrm{Cd}^{2+}$ or $\mathrm{Mn}^{2+}(30 \mathrm{mM} ; n=4)$ in the VML or pyramidal cell body layer failed to reproduce the results obtained with dendritic TTX ejection. Although ejections of TEA $(10 \mathrm{mM})$ in the VML had very little effect $(n=6)$, TEA ejected in the cell body layer immediately reduced the field positivity by $49 \pm 6.7 \%(n=4)$.

The above results suggested that $\sim 50 \%$ of the somatic field positivity could be attributed to potassium conductances associated with somatic spike discharge. The remaining $\sim 50 \%$ was dependent upon dendritic TTX-sensitive conductances, indicating that discharge of a dendritic spike results in outward current flow in the somatic region. We therefore reexamined somatic activity to assess the possible relationship between dendritic $\mathrm{Na}^{+}$spike discharge and somatic membrane potential.

\section{Generation of the somatic depolarizing afterpotential}

Comparison of extra- and intracellular recordings demonstrated that the antidromic field potential positivity aligned with the falling edge of intracellular spikes and the DAP that followed somatic spike discharge (Fig. 9A). The DAP was not a simple reflection of the extracellular response as it was absent on antidromic records evoked at just subthreshold intensity (Fig. $9 A$ ). A separate set of experiments also indicated that the DAP was not simply a $\mathrm{K}^{+}$current generated at potentials below the $\mathrm{K}^{+}$ reversal potential, as ejections of 4-AP $(n=4)$ or TEA $(n=4)$ increased DAP amplitude. We therefore directly tested the role of dendritic $\mathrm{Na}^{+}$spikes in generating the somatic DAP by applying TTX to the proximal apical dendrites.

Focal ejection of TTX through a VML extracellular recording electrode reduced the antidromic dendritic population spike by up to $90 \%$ prior to affecting intrasomatic spike amplitude (Fig. $11 A-C ; n=7$ ). The somatic DAP, however, was blocked by this action in all five cases that originally demonstrated the response (Fig. 11C). Two cells not clearly exhibiting DAPs were unaffected. Subtraction of control from test intrasomatic spikes revealed the DAP as a depolarization of $7.3 \pm 0.66 \mathrm{mV}$ amplitude and $3.0 \pm 0.32 \mathrm{msec}$ duration (Fig. $11 C ; n=5$ ).

In order to compare directly the duration of a dendritic spike to the somatic DAP, antidromic spikes were sequentially recorded in somatic and dendritic impalements in the same slice. We assumed that the latency for spike invasion at the soma was similar in both cases as the dendritic recording was obtained directly above the previous somatic impalement, and the stimulation site and intensity were unchanged. Superimposition of these records demonstrated a correlation between the overall duration of a dendritic spike and the somatic DAP (Fig. 11D; $n=3$ ).

If the somatic DAP is a reflection of dendritic spike discharge, the DAP should exhibit a refractory period. To test this we delivered pairs of antidromic stimuli at varying condition-test (C-T) intervals, and succeeded in differentially blocking the DAP and spike in four of six somatic recordings. In the soma, anti- 
dromic stimulus pairs gradually reduced the test DAP amplitude over a range of $\mathrm{C}-\mathrm{T}$ intervals below $3.8 \mathrm{msec}$, with final blockade at $3.0 \pm 0.17 \mathrm{msec}(n=4$; Fig. $11 E)$. The somatic spike failed in an all-or-none manner at shorter $\mathrm{C}-\mathrm{T}$ intervals $(2.3 \pm 0.2$ msec; $n=6$ ). In dendritic recordings, spikes were reduced in amplitude for C-T intervals below $5 \mathrm{msec}$, and blocked at 4.4 $\pm 0.24 \mathrm{msec}$ (Fig. $11 F ; n=4$ ), a value significantly different from that of somatic spikes $(p<0.001)$. The FPP remaining in the dendrite was reduced in amplitude at shorter C-T intervals and failed at $2.1 \pm 0.18$ (Fig. $11 F ; n=3$ ), a value not significantly different from that of the somatic spike. As the DAP was gradually reduced in amplitude over a range of C-T intervals, it was not possible to compare statistically the refractory period of the DAP to somatic or dendritic spikes. This may be due to a blockade of dendritic spikes at locations progressively closer to the cell body as the C-T interval was reduced. Nevertheless, the above tests revealed that both the somatic DAP and dendritic spike exhibit refractory periods longer than that of the somatic spike.

\section{The DAP and oscillatory discharge in pyramidal cells}

In some cells, the DAP could dramatically alter pyramidal cell output during repetitive spike discharge evoked by depolarizing current injection. At depolarizations beyond spike threshold, these cells exhibited a time-dependent change in spike afterpotentials, apparent as a progressive decrease in the SAHP and an increase in DAP amplitude (Fig. 12B; $n=28$ ). Both factors contributed to the DAP eventually attaining somatic spike threshold, discharging a short-latency spike up to the limit of the refractory period. This resulted in a high-frequency "doublet" spike burst (up to $500 \mathrm{~Hz}$ ) followed by a "postburst AHP" (bAHP) of 5-10 msec. This process was repeated in a consecutive fashion for longer-lasting depolarizations, giving rise to an oscillatory burst of two to six spikes with a period ranging from 38 to $81 \mathrm{~Hz}$ (Fig. $12 D ; 59 \pm 3.7 \mathrm{~Hz}, n=11$ ). As the change in afterpotentials depended upon the rate of spike discharge, it was possible to shift a single cell from a tonic to an oscillatory mode according to the level of current injection $(<1.0$ $\mathrm{nA}$ ). Intrasomatic biocytin injections indicated that these "DAPinduced" oscillations were present in both basilar $(n=5)$ and nonbasilar $(n=7)$ pyramidal cells. In addition, both the magnitude and incidence of oscillatory discharge was more prevalent for cells in the centrolateral segment or in longitudinally sectioned slices (presumed centrolateral or lateral segments) (Turner et al., 1991b).

In order to test the role for dendritic $\mathrm{NaChs}$ in evoking oscillations, we repeated the earlier test of focally ejecting TTX in the proximal dendritic region. As shown in Figure 12, $B$ and $C$ TTX ejections restricted to the VML selectively blocked both

Figure 10. Antidromic field potential responses are TTX insensitive in the distal apical dendritic region. Two extracellular recording electrodes were placed at different points over the cell axis to record the plexiform-evoked antidromic potential. Control responses are superimposed upon those recorded immediately following ejections of $16 \mu \mathrm{M}$ TTX ( $<4$ pulses) through one of the two recording electrodes (denoted by arrows). $A$, Focal TTX ejections in the cell body layer $(P C L)$ simultaneously blocked the population spikes recorded in the PCL and the VML. $B$, TTX ejections through a recording electrode in the VML reduced the VML population spike prior to affecting the negativity of the pyramidal cell population spike. The positive-going field potential
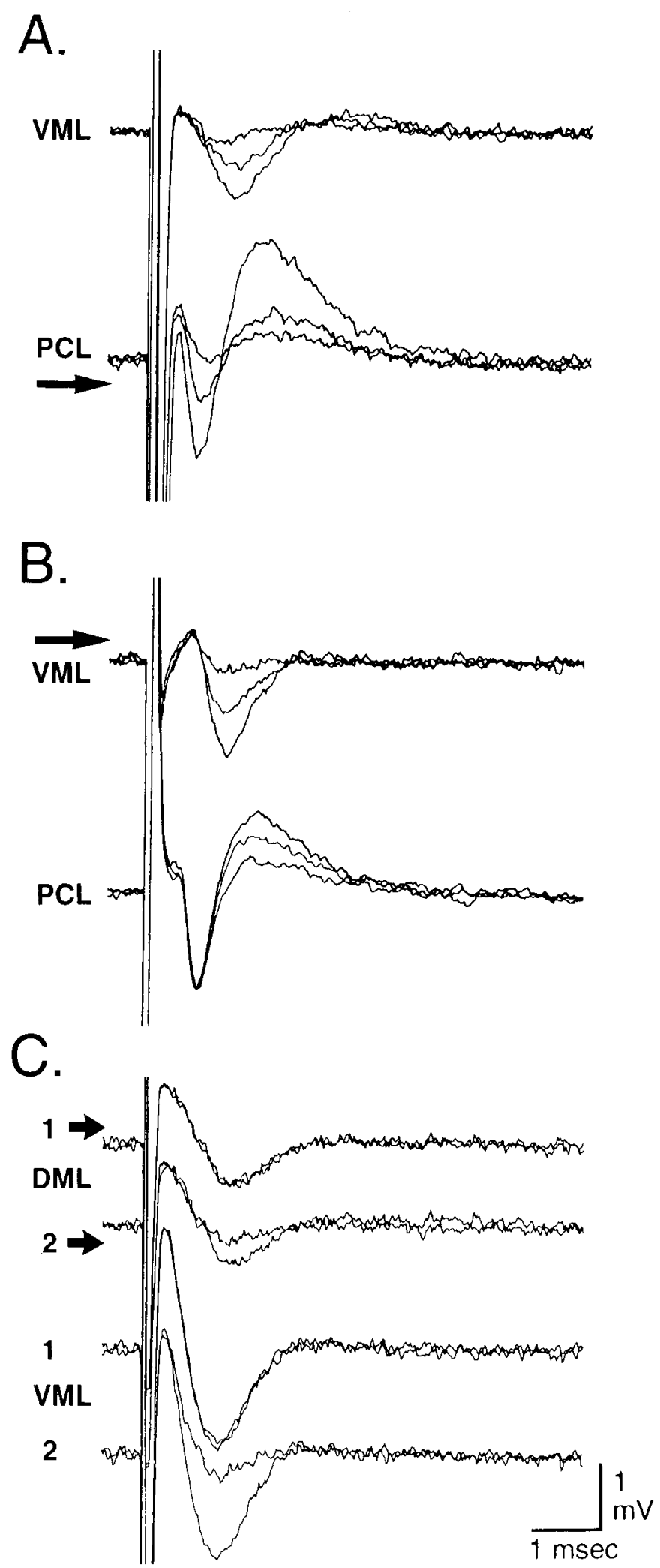

in the PCL was, however, reduced in concert with the VML population spike negativity. $C$, Focal TTX ejections through an electrode in the more distal DML had no effect on the DML population response ( $D M L$ l). A lack of effect on the simultaneously recorded population spike in the VML (VML I) confirms that TTX was localized to the DML at this time. Repetitive TTX ejections (>10 pulses) eventually reduced the DML population response ( $D M L 2$ ), but only if the toxin diffused over a sufficient distance to reduce the population spike in the VML (VML 2). Field potentials are averaged records of three consecutive sweeps. 

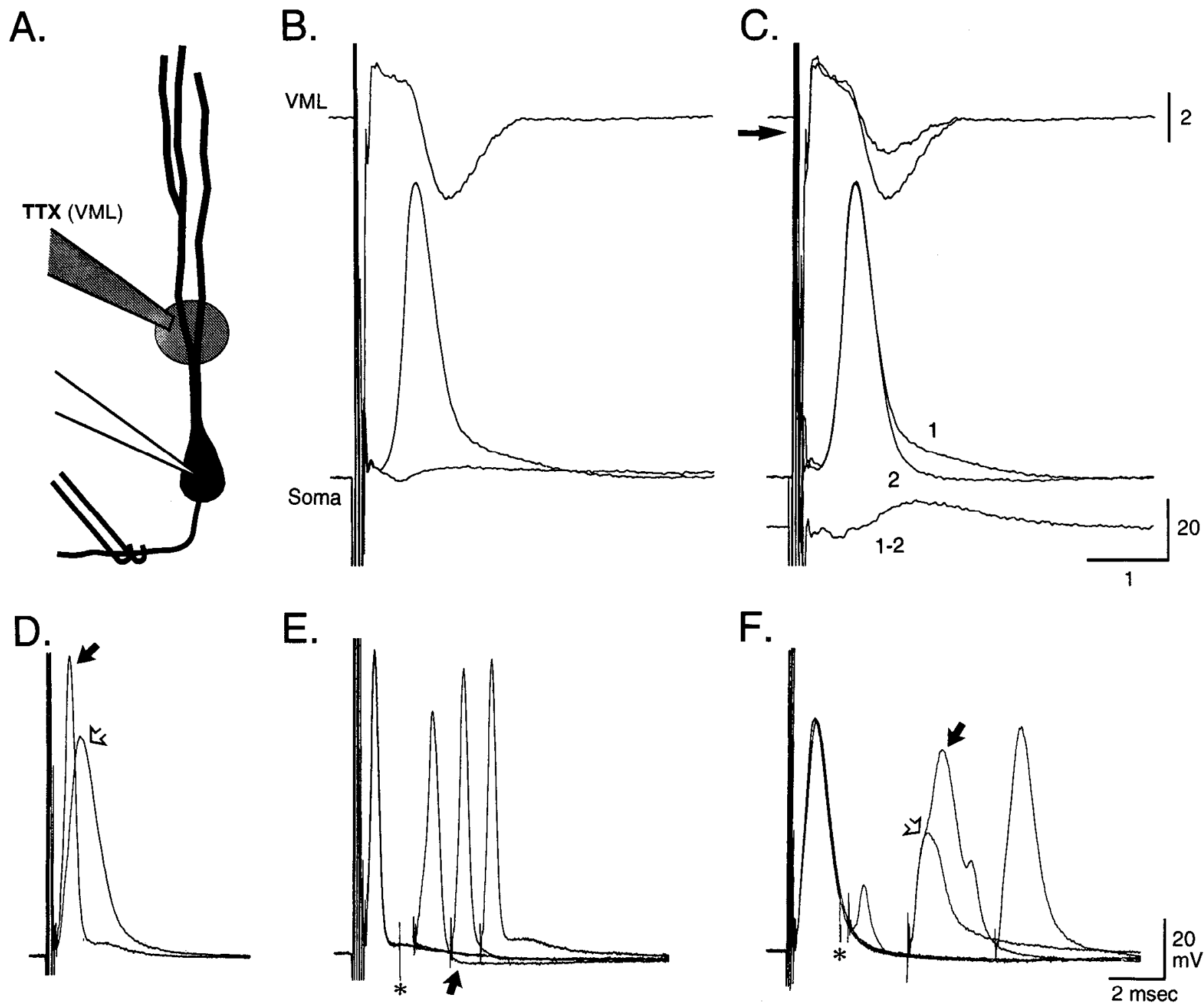

Figure 11. $\mathrm{Na}^{+}$-dependent dendritic spikes generate a somatic depolarizing afterpotential. $A-C$, Blockade of antidromic dendritic spikes by focal TTX ejection blocks the somatic DAP. $A$, Schematic diagram of a pyramidal cell (basilar or nonbasilar cells) illustrating an intrasomatic recording site and the site of TTX ejection in the VML (shaded region) through a TTX-containing extracellular recording electrode. Antidromic spikes were evoked by stimulation of the plexiform layer (paired stimulus wires). $B$ and $C$, The control intrasomatic spike (Soma) and the VML population spike are shown in $B$ and again in $C$ superimposed upon those recorded immediately after TTX ejections in the VML (denoted by arrow in $C$ ). Sub- and suprathreshold responses are shown superimposed in the control records of $B . C$, After TTX ejections, the VML population spike was reduced, but the amplitude of the somatic spike was unchanged, indicating a restriction of TTX to the VML at this time. However, the DAP following the antidromic somatic spike (1) was reduced following TTX ejections (2). The difference between the intracellular recordings (l-2) is shown in the lowest record of $C . D$, Superimposition of antidromic spikes recorded sequentially in a soma (solid arrow) and then dendritic impalement (open arrow) in the same slice using a constant stimulus site and intensity. Note that the duration of the dendritic spike envelopes the somatic DAP. $E$ and $F$, Paired antidromic stimuli at short C-T intervals revealed that both the somatic DAP and dendritic spike exhibit a refractory period greater than the somatic spike. $E$, In a somatic recording, the DAP was progressively reduced at C-T intervals of 2.2-3.8 msec and blocked at $2.3 \mathrm{msec}$ C-T (solid arrow). The somatic spike exhibited an absolute refractory period of $1.7 \mathrm{msec}$ (asterisk). F, A dendritic spike (solid arrow) was blocked at a C-T interval of $4.4 \mathrm{msec}$, revealing a FPP (open arrow). The FPP was reduced in height at shorter C-T intervals, and blocked all-or-none at a $1.9 \mathrm{msec}$ C-T interval (asterisk). The onset of the stimulus artifacts in $E$ and $F$ has been removed to improve the clarity of presentation.

the somatic DAP and doublet spike discharge, while somatic spike amplitude and the progressive decrease in sAHP amplitude remained intact $(n=6)$. In cells cxhibiting DAP-induced oscillations, TTX ejections in the VML rapidly converted pyramidal cell activity from an oscillatory to a tonic discharge mode (Fig. 12D, $E ; n=6$ ). In two cases, these results were repeated three times after recovery from TTX ejections. Notably, the overall mean firing rate for a given step depolarization was unchanged after TTX ejection, indicating that the DAP selectively influenced the pattern of pyramidal cell discharge.

\section{Discussion}

The present study demonstrates that TTX-sensitive NaChs are distributed over somatic and dendritic membranes of ELL pyramidal cells. Furthermore, regional blockade of these channels revealed a soma-dendritic interaction in action potential dis- 
A.

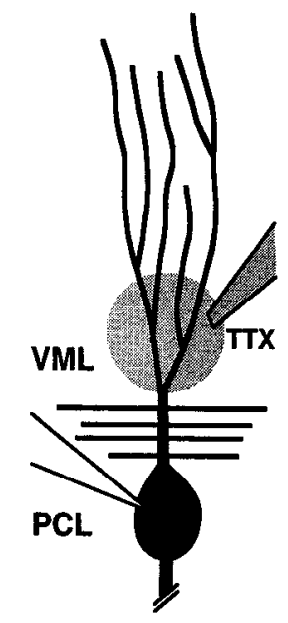

B.

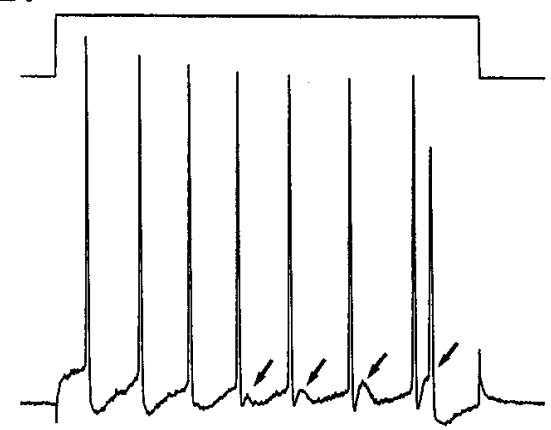

D.

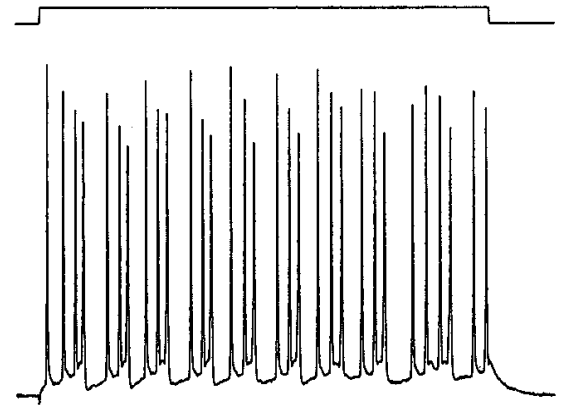

C.

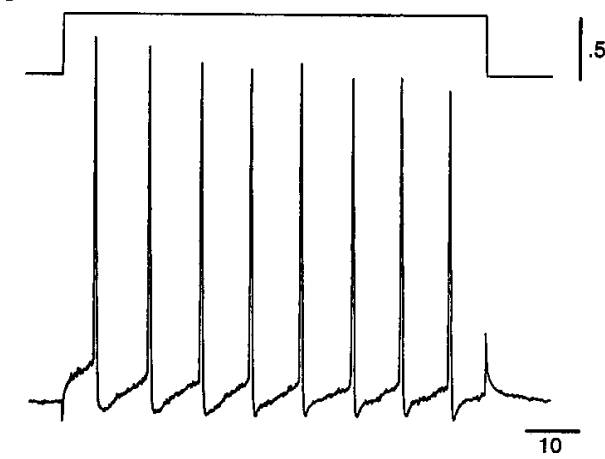

E.

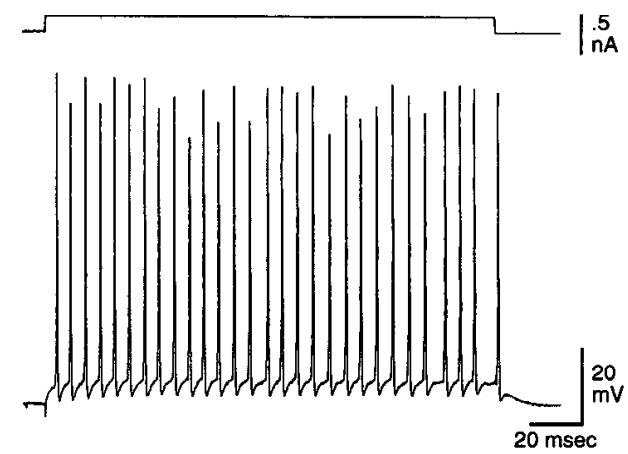

Figure 12. Focal dendritic TTX ejection blocks the somatic DAP and oscillatory discharge in pyramidal cells. $A$, Schematic diagram illustrating intrasomatic recordings from pyramidal cells and the placement of a pressure electrode for focal ejections of $16 \mu \mathrm{M}$ TTX in the VML (shaded region). The horizontal lines separating the PCL and VML denote the thick tSF fiber bundle, while the truncated basal dendrite signifies recordings from both basilar and nonbasilar pyramidal cells. $B$ and $C$, Dendritic TTX ejection blocks the somatic DAP. $B$, Repetitive somatic spike discharge during current injection $(80 \mathrm{msec}$ ) was accompanied by a progressive decrease in sAHP amplitude and an increase in the DAP (arrows). The DAP eventually attained threshold for spike discharge and generated a high-frequency spike doublet (last discharge in spike train) followed by a bAHP. $C$, Focal TTX ejections in the VML selectively blocked the DAP and doublet spike discharge without affecting somatic spike amplitude or the progressive decrease in SAHP amplitude. $D$ and $E$, Dendritic TTX ejection blocks an oscillatory discharge driven by the DAP. $D$, Extended depolarizing current injection $(175 \mathrm{msec})$ in another cell evoked a repetitive series of spike bursts incorporating a sequential decrease in sAHP amplitude, an increase in DAP amplitude, and doublet spike discharge. The bAHP that followed doublet spike discharge appeared to reinstate the process, leading to an oscillatory burst discharge in this cell at a frequency of $56 \pm 2.6 \mathrm{~Hz}(n=9)$. $E$, Focal TTX ejections in the VML selectively blocked the DAP and converted pyramidal cell output from an oscillatory to a tonic discharge without affecting the amplitude or overall frequency of somatic spike discharge.

charge that underlies a form of oscillatory spike discharge. The known response characteristics of pyramidal cells in vivo suggest that these oscillations represent the cellular basis of a temporal filter in a first-order sensory nucleus (Maler, 1989).

$\mathrm{NaChs}$ were immunolocalized in ELL pyramidal cells of weakly electric fish using an antibody directed against $\mathrm{NaCh}$ from the electric organ of Electrophorus electricus (Ellisman and Levinson, 1982). This antibody intensely labels $\mathrm{NaChs}$ localized to axon nodes of Ranvier in both Electrophorus and the Apteronotid species studied here (Ellisman and Levinson, 1982; Devor et al., 1989). Although several $\mathrm{NaCh}$ subtypes from mammalian CNS have been cloned and expressed (Noda et al., 1986a,b; Suzuki et al., 1988; Auld et al., 1990; Joho et al., 1990; Sarao et al., 1991; Schaller et al., 1992), no direct comparisons can be made to our results as the molecular and biophysical characteristics of Apteronotid $\mathrm{NaCh}$ have not been determined. Nevertheless, immunolabel in the present study was correlated with membrane regions containing $\mathrm{NaChs}$ supporting action potential discharge. Given recent evidence for distinct gating modes in NaChs (Moorman et al., 1990; Alzheimer et al., 1993a), it is unclear at the present time as to whether our immunolabel also includes $\mathrm{NaChs}$ contributing to slow prepotential generation.

\section{Dendritic distribution of NaCh immunolabel}

$\mathrm{NaChs}$ have previously been localized by radio- and fluorescently-labeled toxins to neurites and somata of cultured neurons (Catterall, 1981; Boudier et al., 1985; Angelides et al., 1988), and by immunocytochemistry to nodes of Ranvier or axon hillock (Ellisman and Levinson, 1982; Wollner and Catterall, 1986; Black et al., 1989; Devor et al., 1989) and somatic membrane of cells in both culture and intact tissue (Westenbroek et al., 1989; Caffrey et al., 1992). The present study provides the first immunocytochemical localization of $\mathrm{NaChs}$ to dendritic membranes of a vertebrate CNS neuron in intact tissue. Of considerable interest is the fact that basal and apical dendrites exhibited punctate regions of immunolabel, reflecting a localized increase in the density of $\mathrm{NaChs}$. As this was observed at both the light and EM level, these discontinuous "patches" of immunolabel did not appear to connect outside the plane of sectioning. Therefore, this distribution provides the first clear cytochemical correlate for dendritic $\mathrm{NaCh}$ "hot spots," putative sites proposed in other cells to act as the location for dendritic $\mathrm{Na}^{+}$spike discharge (Spencer and Kandel, 1961; Kuno and Llinas, 1970; Wong et al., 1979; Deschênes, 1981; Coleman, 1987; Huguenard et al., 1989; Turner et al., 1991a, 1993; Regehr 
et al., 1993). Although immunolabel was detected on the external surface of parallel fiber boutons in the distal DML, no label was observed in direct association with the neck, head, or postsynaptic density of pyramidal cell dendritic spines. Similarly, immunolabel was not associated with the subsynaptic membrane of terminals impinging on the soma or basal dendrite. Therefore, in ELL pyramidal cells, $\mathrm{NaChs}$ do not associate with dendritic spines, but rather with nonsynaptic membrane of the dendritic shaft or soma, a result that may be of significance for theoretical studies of spine function (Shepherd et al., 1985; Baer and Rinzel, 1991). The mechanism by which NaChs are distributed to and confined at these particular locations is unknown at the present time.

\section{Immunolocalized $\mathrm{NaCh}$ and action potential discharge}

The distribution of $\mathrm{NaCh}$ immunolabel corresponded closely to that of TTX-sensitive action potential discharge in both somatic and dendritic regions of pyramidal cells. $\mathrm{Na}^{+}$-dependent action potentials were reliably generated in both basilar and nonbasilar pyramidal cell somata (Fig. 7; Mathieson and Maler, 1988); a result in agreement with $\mathrm{NaCh}$ immunolabel on somatic membrane. Tissue sections containing an identifiable axon hillock were not obtained for immunocytochemical analysis. Nevertheless, a rapid block of spike discharge following TTX ejections in the plexiform layer suggests that this region also contains a high $\mathrm{NaCh}$ density. The presence of $\mathrm{NaCh}$ immunolabel over the proximal $\sim 200 \mu \mathrm{m}$ of apical dendrites was correlated with action potential discharge, although spikes were of substantially lower amplitude and longer duration than that at the soma. This could result from a less uniform or lower density of $\mathrm{NaChs}$, $\mathrm{NaChs}$ with different kinetic properties (Moorman et al., 1990; Alzheimer et al. 1993a,b), or the specific complement of $\mathrm{K}^{+}$conductances in somatic and dendritic regions. Distal apical dendrites were distinct in that the antidromic population spike in the DML was TTX-insensitive and rapidly decreased in conduction velocity beyond the tSF/VML border. This does not rule out the possible significance of $\mathrm{NaChs}$ in distal dendritic regions, but it does indicate that $\mathrm{NaCh}$ density in distal dendrites is insufficient to promote $\mathrm{Na}^{+}$spike conduction, at least that measured at the level of extracellular field potentials.

Although $\mathrm{NaCh}$ immunolabel was densely distributed over somatic membrane, initial measurements indicated an equivalent voltage threshold for action potential discharge in somatic and dendritic regions. However, TTX ejections revealed a marked difference in the depolarization underlying evoked spikes. Following TTX ejections in the VML, dendritic spikes discharged at short latency on a one-to-one basis with FPPs of up to $29 \mathrm{mV}$; potentials that were in turn generated by spike discharge in the cell body region (Fig. 8). In contrast, FPPs were not uncovered at the soma when somatic spikes were blocked by local TTX ejection, even with high levels of depolarizing current (data not shown). This suggests that apical dendrites generate a spike only when brought to threshold by the additional depolarization provided by the FPP. Superimposition of FPPs on the fast rising phase of dendritic spikes thus prevented us from detecting them when measuring the voltage for action potential discharge. The cell body region then exhibits a lower threshold for spike discharge $(11 \pm 0.9 \mathrm{mV} ; n=20)$ than dendritic membrane, a conclusion that would equate with the stronger $\mathrm{NaCh}$ immunofluorescence on somatic membrane. The ex- act voltage threshold of dendritic membrane has not been determined at this time.

The above data suggest a sequence for the initiation and propagation of $\mathrm{Na}^{+}$spikes over the axis of ELL pyramidal cells when activated by current injection or antidromic stimulation. Current-evoked depolarizations at either the somatic or apical dendritic level initiate spike discharge in the soma-axon hillock region, the location of lowest threshold for spike generation. Once an action potential is discharged at the soma, it is reflected in the proximal apical dendrite as an all-or-none, small-amplitude FPP. The TTX resistance of this response suggests it conducts electrotonically from the soma (Coombs et al., 1957; Carras et al., 1992; Turner et al., 1993), as dendritically recorded FPPs were rapidly blocked by TTX ejections in the cell body region. The FPP in turn discharges at least two active potentials at short latency in the proximal apical dendrite (Fig. $8 \mathrm{C}$ ), the combination of which generates a lower-amplitude, longer-duration dendritic spike. Beyond $\sim 200 \mu \mathrm{m}$ distance, active propagation of the $\mathrm{Na}^{+}$spike fails, and the remaining potential conducts into the distal apical dendrites either passively or by TTXresistant conductances (Wong et al. 1979; Llinas and Sugimori, 1980; Caffrey et al., 1992; Hoehn et al., 1993). The pattern of $\mathrm{Na}^{+}$spike initiation and conduction in response to synaptic depolarization remains to be determined.

\section{Functional significance of NaChs in ELL pyramidal cells}

Oscillatory discharge. We have now obtained direct evidence that a $\mathrm{Na}^{+}$spike retrogradely conducted into the apical dendrites results in a depolarization of somatic membrane in the form of a DAP. Although it is possible the DAP is generated in part by active conductances (Llinas and Yarom, 1981; Valiante et al., 1992; Higashi et al., 1993; Hoehn et al., 1993; Viana et al., 1993; Zhang et al., 1993) triggered by the dendritic spike, local ejections of $\mathrm{Ca}^{2+}$ and $\mathrm{K}^{+}$channel blockers could not reproduce the results obtained by dendritic TTX ejection. Rather, the simplest explanation for the DAP is that the long-duration dendritic spike (3-10 $\mathrm{msec})$ results in a redistribution of current to the cell body region that outlasts the repolarizing phase of the somatic spike. This may occur either directly from dendritic inward current or the discharge of membrane capacitance following retrograde spike invasion. In fact, TIX ejections in the proximal dendritic region reduced the somatic antidromic field positivity (Fig. 10B), a result indicating that current associated with dendritic spike discharge sources at the level of the pyramidal cell body layer.

The DAP dramatically altered pyramidal cell output during repetitive spike discharge as it grew in size to eventually trigger a high-frequency spike doublet (Fig. 12). A bAHP that followed the spike doublet then "reset" the cell. A repetition of this sequence of events resulted in an oscillatory burst of spikes with a period determined by the bAHP. The final outcome of this soma-dendritic interaction in action potential discharge was to convert pyramidal cell output from a tonic to an oscillatory mode. Notably, a retrograde spike invasion of dendritic membrane has been suggested to account for somatic DAPs in lobster stretch receptors (Grampp, 1966; Calvin and Hartline, 1977), mammalian motoneurons (Granit et al., 1963; Nelson and Burke, 1967), dentate gyrus granule cells (Valiante et al., 1992), and hippocampal and neocortical pyramidal cells (Calvin and Sypert, 1976; Storm et al., 1987). In many cases DAPs can modify spike trains by generating short-latency spike doublets or spike 
bursts (Calvin and Sypert, 1976; Calvin and Hartline, 1977; Wong and Prince, 1981; Connors et al., 1982; Steriade et al., 1993; Viana et al., 1993). The mechanism described in the present study for gencrating DAPs and oscillatory spike bursts may then be applicable to a wide range of cell types.

Electrosensory processing. Pyramidal cells of the ELL encode spatial and temporal characteristics of amplitude modulations of an electric organ discharge (EOD) emitted for the purpose of electrolocation and -communication (Bastian, 1986a; Bullock and Heiligenberg, 1986; Metzner and Heiligenberg, 1991). Pyramidal cells in each of the segmental maps exhibit differential response characteristics in vivo, with cells in the centromedial, centrolateral, and lateral segments responding on average to progressively higher frequencies of EOD amplitude modulations (Shumway, 1989). This led Maler (1989) to propose that the ELL acts as a "tunable temporal filter" of EOD amplitude modulations. Consistent with this proposal, lateral segment pyramidal cells preferentially respond to electrocommmunicatory signals (chirps; Metzner and Heiligenberg, 1991) composed of $50-100 \mathrm{~Hz}$ EOD amplitude modulations (Zupanc and Maler, 1994). It is thus significant that DAP-induced oscillatory bursts occur at a frequency of $40-80 \mathrm{~Hz}$, as this falls within the best frequency range for pyramidal cells of the centrolateral and lateral segments in vivo (Shumway, 1989), and corresponds to the frequency of amplitude modulations caused by chirps (Zupanc and Maler, 1994). Indeed, spontaneous spike doublets characteristic of DAP-induced burst firing appear to be most prevalent in these segments in vitro (Turner et al., 1991b). Thus, DAP-induced oscillations may permit pyramidal cells to synchronize their discharge to rapid EOD modulations related to electrolocation or -communication signals.

We therefore hypothesize that the soma-dendritic interaction in spike discharge that results in oscillatory spike bursts represents the cellular basis of a postsynaptic filter that tunes the ELL circuit response to sensory input.

Amplification of synaptic input. Afferents carried in the tSF fiber bundle branch and terminate in the proximal apical dendritic region of pyramidal cells, the same region exhibiting punctate $\mathrm{NaCh}$ immunolabel. Dendritic $\mathrm{NaChs}$ may then act to boost the transmission of tSF synaptic input to the cell body region. It is unknown at this time whether tSF-evoked EPSPs can attain the higher spike threshold of apical dendrites and initiate spike discharge at that level. However, recent evidence has bcen obtained for an augmentation of the ISF EPSP by a slow voltagedependent $\mathrm{Na}^{+}$conductance that may involve $\mathrm{NaChs}$ responsible for the slow prepotential (Plant et al., 1992; Plant and Maler, unpublished observations).

The electrophysiology of pyramidal cell basal dendrites has not yet been determined, but the punctate distribution of $\mathrm{NaCh}$ immunolabel on basal dendrites is optimally positioned to boost primary afferent synaptic depolarizations. This dendritic structure is unique in that excitatory inputs terminate only on the most distal dendritic bush up to $400 \mu \mathrm{m}$ from the cell body (Maler, 1979). Compartmental modeling of pyramidal cells with passive basal dendrites suggests that single EPSPs are severely attenuated and fail to reach spike threshold at the soma (Maler, unpublished observations). These simulations further suggest that a passive basal dendrite acts as a low pass filter incapable of following frequencics over a few hertz. $\Lambda$ s pyramidal cells can follow primary afferent inputs encoding EOD amplitude modulations of over $60 \mathrm{~Hz}$ (Bastian 1986a,b; Shumway 1989), passive temporal integration of basal dendritic EPSPs appears unlikely. These factors would suggest a role for $\mathrm{NaChs}$ in generating basal dendritic spikes, allowing the pyramidal cell to follow rapid changes of primary afferent input. This hypothesis is consistent with a recent theoretical study suggesting that boosting distal inputs by local dendritic conductances permits a sensory neuron to follow rapid fluctuations of synaptic input (Softky and Koch, 1993). Interestingly, the basal dendrite is covered with GABAergic boutons from local and commissural inhibitory interneurons (Maler and Mugnaini, 1994). Thus, the ability for dendritic $\mathrm{NaChs}$ to amplify synaptic depolarizations is itself regulated by local inhibitory input.

FIL. pyramidal cells offer a unique opportunity to examine how the distribution of an ion channel interacts with primary afferent and feedback inputs to encode sensory stimuli. The ability to examine cell response characteristics in vitro or during electrocommunication or electrolocation in vivo (Bastian, 1986a) further makes it possible to investigate cellular interactions in the context of neural circuit function. Future work can thus be expected to define the relationship between oscillatory discharge and the proposed function for the ELL as a set of tunable spatiotemporal filters (Maler, 1989).

\section{References}

Alonso A, Llinas $\mathrm{R}$ (1989) Subthreshold $\mathrm{Na}^{+}$-dependent theta-like rhythmicity in stellate cells of entorhinal cortex layer II. Nature 342 : 175-177.

Alzheimer C, Schwindt PC, Crill WE (1993a) Modal gating of $\mathrm{Na}^{+}$ channels as a mechanism of persistent $\mathrm{Na}^{+}$current in pyramidal neurons from rat and cat sensorimotor cortex. J Neurosci 13:660673.

Alzheimer C, Schwindt PC, Crill WE (1993b) Postnatal development of a persistent $\mathrm{Na}^{+}$current in pyramidal neurons from rat sensorimotor cortex. J Neurophysiol 69:290-292.

Amitai Y, Friedman A, Connors BW, Gutnick MJ (1993) Regenerative activity in apical dendrites of pyramidal cells in neocortex. Cereb Cortex 3:26-38.

Angelides KJ, Elmer LW, Loftus D, Elson E (1988) Distribution and lateral mobility of voltage-dependent sodium channels in neurons. $J$ Cell Biol 106:1911-1925.

Auld VJ, Goldin AL, Krafte DS, Catterall WA, Lester HA, Davidson N, Dunn RJ (1990) A neutral amino acid change in segment IIS4 dramatically alters the gating properties of the voltage-dependent sodium channel. Proc Natl Acad Sci USA 87:323-327.

Baer SM, Rinzel J (1991) Propagation of dendritic spikes mediated by excitable spines: a continuum theory. J Neurophysiol 65:874-890.

Bastian J (1986a) Electrolocation: behavior, anatomy, and physiology. In: Electroreception (Bullock TH, Heiligenberg W, eds), pp 577-612. New York: Wiley.

Bastian J (1986b) Gain control in the electrosensory system mediated by descending inputs to the electrosensory lateral line lobe. J Neurosci 6:553-562.

Bastian J (1990) Electroreception. In: Comparative perception, Vol II, Complex signals (Stebbins WC, Berkley MA, eds), pp 35-88. New York: Wiley.

Bastian J, Courtright J (1991) Morphological correlates of pyramidal cell adaptation rate in the electrosensory lateral line lobe of weakly electric fish. J Comp Physiol 168:393-407.

Benardo L, Masukawa LM, Prince DA (1982) Electrophysiology of isolated hippocampal dendrites. J Neurosci 2:1614-1622.

Black JA, Friedman B, Waxman SG, Elmer LW, Angelides KJ (1989) Immuno-ultrastructural localization of sodium channels at nodes of Ranvier and perinodal astrocyte processes in rat optic nerve. Proc $\mathrm{R}$ Soc Lond [Biol] 238:39-51.

Boudier JA, Berwald-Netter Y, Dellman HD, Boudier JL, Couraud F, Koulakoff A, Cau P (1985) Ultrastructural visualization of $\mathrm{Na}^{+}$channel associated ${ }^{125} \mathrm{I}$-alpha scorpion toxin binding sites on fetal mouse nerve cells in culture. Dev Brain Res 20:137-142. 
Bullock TH, Heiligenberg W, eds (1986) Electroreception. New York: Wiley.

Caffrey JM, Eng DL, Black JA, Waxman SG, Kocsis JD (1992) Three types of sodium channels in adult rat dorsal root ganglion neurons. Brain Res 592:283-297.

Calvin WH, Hartline DK (1977) Retrograde invasion of lobster stretch receptor somata in control of firing rate and extra spike patterning. $\mathbf{J}$ Neurophysiol 40:106-118.

Calvin WH, Sypert GW (1976) Fast and slow pyramidal tract neurons: an intracellular analysis of their contrasting repetitive firing properties in the cat. J Neurophysiol 39:420-434.

Carr CE, Maler L (1986) Electroreception in gymnotiform fish. In: Electroreception (Bullock TH, Heiligenberg W, eds), pp 319-373. New York: Wiley.

Carras PL, Coleman PA, Miller RF (1992) Site of action potential initiation in amphibian retinal ganglion cells. J Neurophysiol 67:292304.

Catterall WA (1981) Localization of sodium channels in cultured nerve cells. J Neurosci 1:777-783.

Catterall WA (1992) Cellular and molecular biology of voltage-gated sodium channels. Physiol Rev [Suppl] 72:15-48.

Coleman HA (1987) Multiple sites for the initiation of action potentials in neurons of the inferior mesenteric ganglion of the guinea-pig. Neuroscience 20:357-363.

Connors BW, Gutnick MJ, Prince DA (1982) Electrophysiological properties of neocortical neurons in vitro. J Neurophysiol 48:13021320.

Coombs JS, Curtis DR, Eccles JC (1957) The interpretation of spike potentials of motoneurons. J Physiol (Lond) 139:198-231.

Deschênes M (1981) Dendritic spikes induced in fast pyramidal tract neurons by thalamic stimulation. Exp Brain Res 43:304-308.

Devor M, Keller CH, Deerinck T, Levinson SR, Ellisman MH (1989) $\mathrm{Na}^{+}$channel accumulation on axolemma of afferents in nerve end neuromas in Apteronotus. Neurosci Lett 102:149-154.

Ellisman MH, Levinson SR (1982) Immunocytochemical localization of sodium channel distributions in the excitable membranes of Electrophorus electricus. Proc Natl Acad Sci USA 79:6707-6711.

Ellisman MH, Maler L, Turner RW, Levinson SR (1988) Distribution of $\mathrm{Na}^{+}$channels on dendrites of identified vertebrate neurons: immunocytochemistry and electrophysiology. XVIII Proc Soc Neurosci $14: 834$.

England JD, Gamboni F, Levinson SR, Finger TE (1990) Changed distribution of sodium channels along demyelinated axons. Proc Natl Acad Sci USA 87:6777-6780.

Grampp W (1966) The impulse activity in different parts of the slowly adapting stretch receptor neuron of the lobster. Acta Physiol Scand 66[Suppl 262]:3-36.

Granit R, Kernell D, Smith RS (1963) Delayed depolarization and the repetitive response to intracellular stimulation of mammalian motoneurones. J Physiol (Lond) 168:890-910.

Heiligenberg W, Keller CH, Metzner W, Kawasaki M (1991) Structure and function of neurons in the complex of the nucleus electrosensorius of the gymnotiform fish Eigenmannia: detection and processing of electric signals in social communication. J Comp Physiol [A] 169: 151-164.

Higashi H, Tanaka E, Inokuchi $\mathrm{H}$, Nishi S (1993) Ionic mechanisms underlying the depolarizing and hyperpolarizing afterpotentials of single spike in guinea-pig cingulate cortical neurons. Neuroscicnec 55 : $129-138$.

Hoehn K, Watson TWJ, MacVicar BA (1993) A novel tetrodotoxininsensitive, slow sodium current in striatal and hippocampal neurons. Neuron 10:543-552.

Horikawa K, Armstrong WE (1988) A versatile means of intracellular labeling: injection of biocytin and its detection with avidin conjugates. J Neurosci Methods 25:1-11.

Huguenard JR, Hamill OP, Prince DA (1989) Sodium channels in dendrites of rat cortical pyramidal neurons. Proc Natl Acad Sci USA $86: 2473-2477$

Jaffe DB, Johnston D, Lasser-Ross N, Lisman JE, Miyakawa H, Ross WN (1992) The spread of $\mathrm{Na}^{+}$spikes determines the pattern of dendritic $\mathrm{Ca}^{2+}$ entry into hippocampal neurons. Nature 357:244-246.

Jefferys JGR (1979) Initiation and spread of action potentials in granule cells maintained in vitro in slices of guinea-pig hippocampus. $J$ Physiol (Lond) 289:375-388.

Joho RH, Moorman JR, VanDongen AMJ, Kirsch GE, Silberberg H,
Schuster G, Brown AM (1990) Toxin and kinetic profile of rat brain type III sodium channcls cxpressed in Xenopus oocytcs. Mol Brain Res 7:105-113.

Kim HG, Connors BW (1993) Apical dendrites of the neocortex: correlation between sodium- and calcium-dependent spiking and pyramidal cell morphology. J Neurosci 13:5301-5311.

Kuno M, Llinas R (1970) Enhancement of synaptic transmission by dendritic potentials in chromatolysed motoneurons in the cat. J Physiol (Lond) 210:807-821.

Llinas R (1988) The intrinsic electrophysiological properties of mammalian neurons: insights into central nervous system function. Science 242:1654-1664.

Llinas R, Sugimori M (1980) Electrophysiological properties of $i$ vitro Purkinje cell dendrites in mammalian cerebellar slices. J Physiol (Lond) 305:197-213.

Llinas R, Yarom Y (1981) Propertics and distribution of ionic conductances generating electroresponsiveness of mammalian inferior olivary neurons in vitro. J Physiol (Lond) 315:569-584.

MacVicar BA, Dudek FE (1982) Electrotonic coupling between granule cells of dentate gyrus: physiological and anatomical evidence. $J$ Neurophysiol 47:579-592.

Maler L (1979) The posterior lateral line lobe of certain gymnotoid fish: quantitative light microscopy. J Comp Neurol 183:323-363.

Maler L (1989) The role of feedback pathways in the modulation of receptive fields: an example from the electrosensory system. In: Proceedings of the $2 \mathrm{~d}$ international congress on neuroethology, Neural mechanisms of behavior (Erber J, Menzel R, Pfluger HJ, Todt D, eds), pp 111-115. New York: Thieme.

Maler L, Mugnaini E (1994) Correlating GABAergic circuits and sensory function in the clcctrosensory lateral linc lobe (ELL) of a gymnotiform fish. $J$ Comp Neurol, in press.

Maler L, Sas E, Rogers J (1981) The cytology of the posterior lateral line lobe of high frequency weakly electric fish (Gymnotidae): dendritic differentiation and synaptic specificity in a simple cortex. $\mathrm{J}$ Comp Neurol 195:87-139.

Maler L, Sas E, Carr CE, Matsubara J (1982) Efferent projections of the posterior lateral line lobe in gymnotiform fish. J Comp Neurol 211:154-164.

Maler L, Sas E, Johnston SA, Ellis WG (1991) An atlas of the brain of the electric fish Apteronotus leptorhynchus. J Chem Neuroanat 4:138.

Mandel G (1992) Tissue-specific expression of the voltage-sensitive sodium channel. J Membr Biol 125:193-205.

Masukawa LM, Hansen AJ, Shcpherd G (1991) Distribution of singlcchannel conductances in cultured rat hippocampal neurons. Cell Mol Neurobiol 11:231-243.

Mathieson WB, Maler L (1988) Morphological and electrophysiological properties of a novel in vitro slice preparation: the electrosensory lateral line lobe brain slice. J Comp Physiol 163:489-506.

McLean IW, Nakane PK (1974) Periodate-lysine-paraformaldehyde fixative: a new fixative for immunoelectron microscopy. J Histochem Cytochem 22:1077-1083.

Metzner W, Heiligenberg W (1991) The coding of signals in the electric communication of the gymnotiform fish Eigenmannia: from electroreceptors to neurons in the torus semicircularis of the midbrain. $J$ Comp Physiol [A] 169:135-150.

Moorman JR, Kirsch GE, VanDongen AMJ, Joho H, Brown AM (1990) Fast and slow gating of sodium channcls cncoded by a single mRNA. Neuron 4:243-252.

Nelson PG, Burke RE (1967) Delayed depolarization in cat spinal motoneurons. Exp Neurol 17:16-26.

Noda M, Ikeda T, Kayano T, Suzuki H, Takeshima H, Kurasaki M, Takahashi H, Numa $S$ (1986a) Existence of distinct sodium channel messenger RNAs in rat brain. Nature 320:188-192.

Noda M, Ikeda T, Suzuki H, Takeshima H, Takahashi T, Kuno M, Numa S (1986b) Expression of functional sodium channels from cloned cDNA. Nature 322:826-828.

Plant JR, Turner RW, Maler L (1992) Fast NMDA transmission in a sensory feedback pathway. XXII Proc Soc Neurosci 18:348.

Regehr W, Kehoe J, Ascher P, Armstrong C (1993) Synaptically triggered action potentials in dendrites. Neuron 11:145-151.

Richardson TL, Turner RW, Miller JJ (1987) Action potential discharge in hippocampal CAl pyramidal neurons: current source-density analysis. J Neurophysiol 58:981-996.

Sarao R, Gupta SK, Auld VJ, Dunn RJ (1991) Developmentally reg- 
ulated alternative RNA splicing of rat brain sodium channel mRNAs Nucleic Acids Res 19:5673-5679.

Saunders J, Bastian J (1984) The physiology and morphology of two types of electrosensory neurons in the weakly electric fish Apteronotus leptorhynchus. J Comp Physiol [A] 154:199-209.

Schaller KL, Krzemien DM, McKenna NM, Caldwell JH (1992) Alternatively spliced sodium channel transcripts in brain and muscle J Neurosci 12:1370-1381.

Schwindt P, Spain WJ, Crill WE (1989) Long-lasting reduction of excitability by a sodium-dependent potassium current in cat neocortical neurons. J Neurophysiol 61:233-244.

Shepherd GM, Brayton RK, Miller JP, Segev I, Rinzel J, Rall W (1985) Signal enhanccment in distal cortical dendrites by means of interaction between active dendritic spines. Proc Natl Acad Sci USA 82: 2192-2195.

Shumway CA (1989) Multiple electrosensory maps in the medulla of weakly electric gymnotiform fish. I. Physiological differences. J Neurosci 9:4388-4399.

Softky WR, Koch C (1993) The highly irregular firing of cortical cells is inconsistent with temporal integration of random EPSPs. J Neurosci 13:334-350.

Spencer WA, Kandel ER (1961) Electrophysiology of hippocampal neurons. IV. Fast pre-potentials. J Neurophysiol 24:272-285.

Stafstrom CE, Schwindt PC, Crill WE (1982) Negative slope conductance due to a persistent subthreshold sodium current in cat neocortical neurons in vitro. Brain Res 236:221-226.

Stafstrom CE, Schwindt PC, Chubb MC, Crill WE (1985) Properties of persistent sodium conductance and calcium conductance of Layer $\mathrm{V}$ neurons from cat sensorimotor cortex in vitro. J Neurophysiol 53: 153-170.

Steriade M, Dossi RC, Contreras D (1993) Electrophysiological properties of intralaminar thalamocortical cells discharging rhythmic $(\sim 40$ $\mathrm{Hz}$ ) spike-bursts at $\sim 1000 \mathrm{~Hz}$ during waking and rapid eye movement sleep. Neuroscience 56:1-9.

Storm JF, Borg-Graham L, Adams PR (1987) A passive component of the afterdepolarization (ADP) in rat hippocampal pyramidal cells. Biophys J 51:65a.

Stuart GJ, Sakmann B (1994) Active propagation of somatic action potentials into neocortical pyramidal cell dendrites. Nature 367:6972.

Stys PK, Sontheimer H, Ransom BR, Waxman SG (1993) Non-inactivating, TTX-sensitive $\mathrm{Na}^{+}$conductance in rat optic nerve axons. Proc Natl Acad Sci USA 90:6976-6980.
Suzuki H, Beckh S, Kubo H, Yahagi N, Ishida H, Kayano T, Noda M, Numa S (1988) Functional expression of cloned cDNA encoding sodium channel III. FEBS Lett 228:195-200.

Turner RW, Meyers DER, Barker JL (1989) Localization of tetrodotoxin-sensitive field potentials of CAl pyramidal cells in the rat hippocampus. J Neurophysiol 62:1375-1387.

Turner RW, Meyers DER, Richardson TL, Barker JL (1991a) The site for initiation of action potential discharge over the somato-dendritic axis of rat hippocampal CA1 pyramidal neurons. J Neurosci $11: 2270-2280$.

Turner RW, Plant J, Maler L. (1991b) Conditional oscillatory discharge in topographic maps of the electrosensory lateral line lobe. XXI Proc Soc Neurosci 17:1405.

Turner RW, Meyers DER, Barker JL (1993) Fast pre-potential generation in rat hippocampal CA1 pyramidal neurons. Neuroscience 53:949-959.

Valiante TA, Zhang L, Gurevich N, Carlen PL (1992) Depolarizing afterpotentials and the $\mathrm{T}$-type calcium current in hippocampal dentate granule neurons: experimental and computer simulations. XXIInd Proc Soc Neurosci 18:973.

Viana F, Bayliss DA, Berger AJ (1993) Calcium conductances and their role in the firing behavior of neonatal rat hypoglossal motoneurons. J Neurophysiol 69:2137-2149.

Westenbroek RE, Merrick DK, Catterall WA (1989) Differential subcellular localization of the RI and RII Na+ channel subtypes in central neurons. Neuron 3:695-704.

Wollner DA, Catterall WA (1986) Localization of sodium channels in axon hillocks and initial segments of retinal ganglion cells. Proc Natl Acad Sci USA 83:8424-8428.

Wong RKS, Prince DA (1981) Afterpotential generation in hippocampal pyramidal cells. J Neurophysiol 45:86-97.

Wong RKS, Prince DA, Basbaum AI (1979) Intradendritic recordings from hippocampal neurons. Proc Natl Acad Sci USA 76:986-990.

Zhang L, Valiante TA, Carlen PL (1993) Contribution of the lowthreshold $\mathrm{T}$-type calcium current in generating the post-spike depolarizing afterpotential in dentate granule neurons of immature rats. J Neurophysiol 70:1-9.

Zupanc GKH, Maler L (1994) Evoked chirping in the weakly electric fish, Apteronotus leptorhynchus: a quantitative biophysical analysis. Can J Zool 71:2301-2310. 